\title{
An agent-based model of climate-energy policies to promote wind propulsion technology in shipping
}

\begin{abstract}
The global trade share of international shipping is approximately $80 \%$ and it is therefore critical to the global economy. Carbon emissions from international shipping are expected to increase significantly in line with global trade trends. Several niche technologies for ship propulsion provide solutions to reduce shipping $\mathrm{CO}_{2}$ emissions. These technologies face innovation barriers that potentially limit their diffusion. An agent-based model is developed to explore the effect of imperfect agent information and split incentives barriers that current shipping models omit. A transitions perspective is adopted to analyze the diffusion of Flettner rotor technology in time charter drybulk shipping with the model. Simulation results are more conservative compared to those models and show how barriers impact the diffusion of rotor technology, even on favourable shipping routes. The simultaneous introduction of carbon pricing and demonstration projects greatly increases $\mathrm{CO}_{2}$ emission reductions to 2050 relative to either policy introduced in isolation.
\end{abstract}

Keywords: agent-based model, shipping, emissions, transition.

\section{Introduction}

Anthropogenic greenhouse gas (GHG) emissions increase global temperatures, with severe implications for people and ecosystems should these emissions continue to grow unabated (IPCC, 2014). Under the Paris Agreement parties have agreed to implement measures to mitigate emissions and limit the global temperature increase to less than $2^{\circ} \mathrm{C}$ above pre-industrial levels (UNFCCC, 2015). International shipping generated around 2\% of global $\mathrm{CO}_{2}$ emissions in 2012 (Smith et al., 2014). Shipping $\mathrm{CO}_{2}$ emissions could increase $50-250 \%$ by 2050 without further mitigation (Smith et al., 2014), and reach 10-25\% of global emissions as other sectors decarbonise (Kennedy et al., 2011; Cames et al., 2015).

It is imperative that shipping reorients towards a low carbon trajectory for climate mitigation. Forecasts to 2050 show that shipping emission reductions of $35-40 \%$ might be possible with current policies, however net emissions are expected to continue to rise even under optimistic scenario assumptions (Bazari and Longva, 2011). Additional policies are required to encourage the diffusion of energy efficiency innovations in shipping and drive decarbonisation in line with the $2{ }^{\circ} \mathrm{C}$ target of the Paris Agreement (Buhaug et al., 2009; Wang et al., 2010; Eide et al., 2011; Wang and Lutsey, 2013). Shipping innovations include wind propulsion technologies such as Flettner rotors, kites, and sails that can complement conventional technologies (Traut et al., 2014; Lloyd's Register, 2015; 
Nelissen et al., 2016). It is proposed that 10-60\% emission reductions might be possible, dependent on operational speed, the technology, and wind conditions (Smith et al., 2013a).

Several barriers constrain the diffusion of more energy efficient technologies in shipping, despite their potential (Rojon and Dieperink, 2014; Rehmatulla et al., 2017a). Many of these energy efficient technologies are applicable to ships operating under short-term time charter contracts which are prone to the split incentives and imperfect information barriers (Rehmatulla et al., 2017b). Under time charter contracts ship charterers cover their fuel costs whilst shipowners cover operational and capital costs that include investments in energy efficient technologies. Shipowner incentives to invest in energy efficiency measures and reduce fuel costs for charterers are low because the potential increase in their revenues from higher time charter rates are limited (Ådland et al., 2017).

Policies to remove such barriers include carbon pricing (Buhaug et al., 2009), and demonstration projects which publish results in the public domain (Rehmatulla et al., 2017b). The question is whether these policies can overcome the barriers documented in the literature (Rehmatulla et al., 2015). This paper aims to address this question and provide an understanding of how barriers and related policies can affect the shipping transition. Policies cannot draw on the experience and insights of historical shipping transitions which saw a move towards more carbon intensive ships (Geels, 2002). A transition towards a low carbon trajectory is required for which there is scarce experience (Papachristos, 2014). Modelling and simulation is warranted to explore alternative, future transition outcomes and their mechanisms (Papachristos, 2018a).

The methodological aim for this paper is to demonstrate how the qualitative understanding of barriers in the shipping sector can be integrated with a modelling approach to explore the diffusion of wind propulsion in the current shipping transition. The aim is to explore the effect of barriers in a stepwise manner and improve the insights and conclusions of more detailed, techno-economic models used to evaluate decarbonisation policies for the shipping sector, such as the Global Transport Model (Smith et al., 2016; Raucci et al., 2017), or the model used in Nelissen et al. (2016). This exploratory model does not include all the relevant barriers to energy efficiency in the shipping transition, and thus the model in its current form is not intended to generate precise forecasts of wind propulsion diffusion in shipping.

The paper adopts the Multi-Level Perspective (MLP) to conceptually frame the analysis (Geels, 2004; Geels and Schot, 2007), for two reasons. First, because the MLP has been used in previous exemplary shipping transition cases (Geels, 2002). Second, because the alternative ship propulsion technologies exhibit an add-on and hybridization pattern that has been analysed under the MLP (Geels and Schot, 2007; Mander, 2017). In this pattern, niche technologies can develop symbiotic relationships with conventional technologies if they can resolve environmental issues and improve performance. The paper focuses on rotor technology within drybulk shipping because it represents a 
feasible add-on technology to conventional oil fueled propulsion technologies (Nelissen et al., 2016). Based on this MLP conceptualization, an agent-based model (ABM) is developed to explore the effect of barriers on Flettner rotor technology diffusion in the time charter drybulk shipping sector on a route with favourable wind conditions.

The rest of the paper is structured as follows. Section 2 provides the background to the MLP, niche-based innovations and an overview of the international shipping context and modelling work performed to date. Section 3 develops the ABM and presents simulation scenarios and sensitivity analysis results. Section 4 discusses results, limitations of the study and future work and section 5 concludes the paper.

\section{Background}

Section 2.1 outlines briefly the MLP and discusses the extensive literature on transitions and niche. This is used in section 2.2 to conceptualize the shipping transition and the barriers that alternative propulsion technologies face. Section 2.3 provides an overview of modelling applications in the shipping sector to contextualize the model developed in this paper.

\subsection{The multi-level perspective}

The MLP is a sociotechnical framework that facilitates the analysis of system innovation and system wide technological diffusion (Geels, 2002; 2004; Geels and Schot, 2007; Papachristos et al., 2013; Geels et al., 2016). The framework integrates technological concepts from evolutionary economics (Nelson and Winter, 1982) and wider sociological rules (Rip and Kemp, 1998) that account for social group dynamics that influence system change and inertia.

The sociotechnical regime is the core MLP concept for the analysis of actor activities that reproduce system elements. The actors are embedded in interdependent social groups, each with its own regime (set of rules). The MLP distinguishes between technological, cultural, science, markets, industry and policy regimes (Geels and Schot, 2007). The sociotechnical regime refers to the interregime alignment and coordination of intergroup activities that generate path dependency and stabilize sociotechnical trajectories towards a system lock-in state (Unruh, 2000). The MLP has two additional analytical concepts (Geels, 2004): (i) the landscape at the macro level provides gradients for sociotechnical system trajectories which represent exogenous factors, such as oil prices or economic growth, which influence both niches and incumbent regimes, and (ii) the niche level where radical innovations incubate and proliferate protected from external influences.

Within the MLP, transitions unfold when the incumbent sociotechnical regime is destabilised through reinforcing and disrupting interactions that develop between these three levels through (Geels and Schot, 2007): (i) niche technologies that may develop through learning, price and performance 
improvements and support from powerful groups, (ii) landscape trends that exert pressure on the regime (economic, cultural, demographic and other), (iii) internal regime tensions that can accumulate and create windows of opportunity for innovations in niches, and (iv) external influence from other systems, regimes or niches (Papachristos et al., 2013). The transition is completed when the social and technical aspects of novel innovations become embedded in the new sociotechnical system.

In the MLP, niches provide passive or active shielding to "crude and inefficient" innovations from regime market selection pressures (Rosenberg, 1976; Schot et al., 1994; Kemp et al., 1998; Smith and Raven, 2012). The MLP has been applied to the maritime transition from sailing ships to steamships (Geels, 2002), and the rise of slow steaming and wind propulsion (Mander, 2017) where innovation niches facilitate technological experimentation to reduce $\mathrm{CO}_{2}$ emissions (Rehmatulla et al., 2017b). An example of passive shielding for wind propulsion technologies are shipping routes with favourable wind conditions (Nelissen et al., 2016; Mander, 2017). Active shielding involves some form of actor network to support demonstration projects of new propulsion technologies (Raven et al., 2016).

Niche shielding offers the necessary space for technological experimentation and learning processes that provide the basis for the development of actor expectations about niche technologies. Technological experimentation contributes to learning; niche actors revise their expectations towards technologies, communicate these changes through their networks, and attract more actors if expectations become more positive (Rogers, 2003). Learning concerns the niche innovation performance, user requirements and barriers to use, any associated infrastructure requirements, environmental impacts, and government policies (Hoogma et al., 2002). Niche actors play an important role as they provide insights into technology requirements, and share lessons about markets and related barriers (Kemp et al., 1998; Smith and Raven, 2012).

Actor expectations form around the innovation technology, its performance and market potential, and they are critical for niche support (Hoogma et al., 2002). Actor expectation convergence and alignment enable actor enlistment for niche support and increase its structuration (Geels, 2004). If niche innovations are credible and provide solutions to societal issues then they attract actor support (Kemp et al., 1998). For example, networked actor interactions enable resource pooling, and access to technology development resources (Rogers, 2003; Schot and Geels, 2008). Then, actor network growth adds momentum to the innovations and enables niche scale-up (Schot and Geels, 2008; Smith and Raven, 2012; Naber et al., 2017). Actor expectations can also be driven by external niche developments (Budde et al., 2012; Bakker et al., 2014).

The recursive process of expectation convergence, network formation, and learning is continuous, and increases actor alignment and the structuration of niche rules and technological elements (Schot and Geels, 2007). As the momentum of an innovation builds and the rules around 
the technology stabilize and provide a foundation for commercialisation, the focus of niche experimentation shifts from initial exploration and demonstration to full-scale replication (Hoogma, 2000; Schot and Geels, 2007). Innovation niches become market niches that challenge the incumbent regime as their market share increases. However, poor results from niche experiments may drive actor expectations down, and lead to a boom and bust cycle (Alkemade and Suurs, 2012; van Lente et al., 2013), or niche extinction as supporters leave the innovation niche or network (Hoogma et al., 2002).

\subsection{International shipping barriers to energy efficiency}

Innovation barriers are mechanisms that prevent decisions on cost-effective investments in energy efficient technologies, and result in an energy efficiency gap between the expected and optimal energy use (Jaffe and Stavins, 1994; Sorrell et al., 2004). The literature on barriers to energy efficiency in shipping is considerable but the variety of conceptual frameworks makes cross comparison difficult (Jafarzadeh and Utne, 2014; Johnson et al., 2014; Rojon and Dieperink, 2014; Rehmatulla and Smith, 2015; Johnson and Andersson, 2016; Nelissen et al., 2016; Rehmatulla et al., 2017b).

Barriers in shipping include imperfect information on technological performance, and split incentives in the short-term time charter market where shipowner investments in new technologies are not rewarded through increased charter premiums (Agnolucci et al., 2014; Prakash et al., 2016; Ådland et al., 2017). Other significant barriers include access to capital, technical risk, incompatible infrastructure, and economic risks such as uncertain oil prices or lower fleet utilisation (Rojon and Dieperink, 2014; Jafarzadeh and Utne, 2014; Nelissen et al., 2016; Johnson and Andersson, 2016; Rehmatulla et al., 2017b).

Several policies to overcome such barriers exist: (i) carbon pricing (Buhaug et al., 2009; IMO, 2010; Nelissen et al., 2016; Baranzini et al., 2017), (ii) demonstration projects for innovative technologies, either operated, funded, or supported through public institutions such as the IMO which disseminates performance data from full-scale trials to raise expectations and knowledge of alternative technologies (Rojon and Dieperink, 2014; Nelissen et al., 2016; Rehmatulla et al., 2017b), (iii) access to capital through public funding (Nelissen et al., 2016), and (iv) speed limit introduction (Rehmatulla and Smith, 2015; Mander, 2017). The effectiveness of such policies varies; some policies could result in negative distributional impacts and harm international trade (IMO, 2010; Vivid Economics, 2010). In some instances, localised speed limits could deliver limited emission reductions but with high economic costs (Cariou and Cheaitou, 2012).

\subsection{Modelling the diffusion of energy efficiency innovations within shipping}

The current diffusion models of energy efficient technology in shipping do not consider these barriers in any detail and thus cannot effectively assess the effectiveness of related policies. A variety of 
modelling approaches have been used so far in relation to the diffusion of innovations in shipping. Senger and Köhler (2015) explore research and development and shipyard investment decisions, and subsequent technological change on wind propulsion technologies through an ABM. The model includes global shipping demand, variable fuel prices, and policies such as emission standards, and facilitates the exploration of global fleet evolution and wind propulsion adoption. However, the model does not distinguish between shipowners and charterers therefore it cannot be used to explore the important impact of the split incentives barrier.

Nelissen et al. (2016) develop a model with technology learning effects to explore the diffusion of wind propulsion. The model accounts for fuel savings and uses actual cost estimates for wind technologies, an important consideration as investment in wind propulsion can be sensitive to capital costs and realised fuel savings. Model results suggest that wind technology diffusion could be selfsustaining from 2020 onwards. This is relatively optimistic when contrasted with the current limited uptake of wind propulsion in shipping (Rehmatulla et al., 2017b). A reason for this apparent overestimate is that the model neglects key barriers such as imperfect information or split incentives, as the authors note.

Rehmatulla et al. (2015) develop a heuristic approach to forecast technology diffusion within shipping using actual data to inform their diffusion estimate and explicitly take account of current industry barriers. Their results show that diffusion is driven more by imitation rather than actor innovation, due to shipping industry's risk-averse nature (Rojon and Dieperink, 2014). The approach of Rehmatulla et al. (2015) considers technological attributes and associated barriers through coefficients of innovation and imitation that influence diffusion s-curves. Nevertheless, their approach cannot account for diffusion process discontinuities such as new policy introduction or sociotechnical landscape changes because it is not a generative approach (Epstein and Axtell, 1996; Epstein, 2007). The implication is that their approach can offer at best a quasi-explanation for the complete lack of wind propulsion diffusion but it cannot completely explain it (Rehmatulla et al., 2017a).

The review of relevant modelling work in shipping leads to three requirements for modelling work: (i) distinguish between shipowners and charterers, (ii) include key barriers such as imperfect information or split incentives, and (iii) follow a generative approach to facilitate understanding and assessment of the effect of key policies on the adoption of wind propulsion technologies. The following sections present such a generative approach.

\section{An agent-based model}

ABMs use goal-directed agents that interact and respond to environmental stimuli (Tesfatsion, 2006). Agent interactions produce emergent behavior and system properties that are not prescribed in agent 
behavior (Epstein and Axtell, 1996; Epstein, 2007). Agent-based and system dynamics modelling are some of the methods often used in sociotechnical transitions research (Safarzyńska and van den Bergh, 2010; Safarzynska et al., 2012; Holtz et al., 2015; Köhler et al., 2018; Papachristos, 2011; Papachristos, 2017; Papachristos, 2018b). ABMs have certain advantages when it comes to exploring the behavior of complex adaptive systems as they: (i) provide explicit and systematic representations that allow experimentation, and (ii) generate complex system behavior from underlying mechanisms and processes and thus they facilitate the inference of insights about system behaviour. Model results represent alternative futures from which insights can be drawn, rather than accurate predictions (Holtz et al., 2015). A range of challenges remain for agent-based modelling such as the diversity of modelling techniques, and limited model comparability resulting from different theoretical contexts, which highlights the importance of empirical validation (Windrum et al., 2007). The issues noted above will be addressed in the following sections.

\subsection{Model development}

The description of the model developed within this paper follows the "Overview, Design concepts, and Details" protocol in a condensed form (Grimm et al., 2010), and draws upon the work of Lopolito et al. (2013; 2014). Their approach has clear advantages: (i) it utilises an established theoretical context to model processes and agent behaviours, a key issue with agent-based modelling (Windrum et al., 2007); and (ii) it focuses on three key mechanisms which improve model transparency and facilitate analysis: converging agent expectations, networking, and agent learning. The model in Lopolito et al. $(2013 ; 2014)$ was obtained from the authors, developed further to include the imperfect information and split incentives barriers for time charter shipping, and modified to fit the context of rotor propulsion diffusion in shipping. Adjustments include expectations and knowledge spillover effects through communication channels or networks (Rogers, 2003).

\subsubsection{Agents and their environment}

This model simulates rotor diffusion for 100 shipowners within the 60,000-99,999 deadweight tonnage ('dwt') drybulk shipping sector. It is assumed that each shipowner owns a single ship and makes investments to maximise profit (Raucci et al., 2017). One month is deemed a reasonable time interval for shipowner investment decisions. The ships are retrofitted to install rotor technology so that total ship number remains constant. Two agent types directly interact with shipowners: technology providers $(n=2)$, and a shipyard $(n=1)$. Charterer agents are not included explicitly as the focus is on shipowners and their adoption behavior for rotor technology, however, the model formulation does consider the impact of their expectations on rotor diffusion. This approach also 
improves model tractability. ${ }^{1}$ In addition, agents can interact with demonstration projects within the model's social space (where the number of projects is varied in line with the simulated policy).

Interactions between shipowners occur in a social space represented by a wrapped grid of 33 cells by 33 cells. These interactions facilitate information exchange through networking. Technological risk is captured through the random generation of grey cells in each period using a risk variable in the model. These grey cells represent the operational failure of niche technologies (explained in Process 1 below). Technology providers interact with shipowners in the grid, and increase shipowner expectations towards rotor technology performance (Kemp et al., 1998). Each period, technology providers move to the nearest shipowner agent whose expectations are below a defined threshold and increase the shipowner's expectations (representing the impact of marketing). Technology providers then move away from the shipowner by a defined distance in a random direction and move to another shipowner in the following period. Shipyards are simple agents that move in a random direction in the social space. A shipowner must be within a defined radius of a shipyard within social space to install rotor technology. ${ }^{2}$

Socio-technical landscape pressures such as oil and carbon prices are included in the shipowner profit function. The model runs over 360 months from 2020-2050, to allow comparison of results with recent shipping models (Nelissen et al., 2016; Raucci et al., 2017). The model runs sequentially through 12 processes, outlined in detail in the following paragraphs. Figure 1 provides an overview of how these 12 processes interact and the next section discusses model formulae, agent logic and the underlying assumptions made. ${ }^{3}$

\footnotetext{
${ }^{1}$ An extension of this model should certainly consider the inclusion of charterers as an explicit agent type.

${ }^{2}$ As noted above, the model has been kept simple to improve the tractability of results. See Senger and Köhler (2015) for an example of how R\&D within shipyards could be treated within an extended model.

${ }^{3}$ The model code is available from the authors upon request.
} 


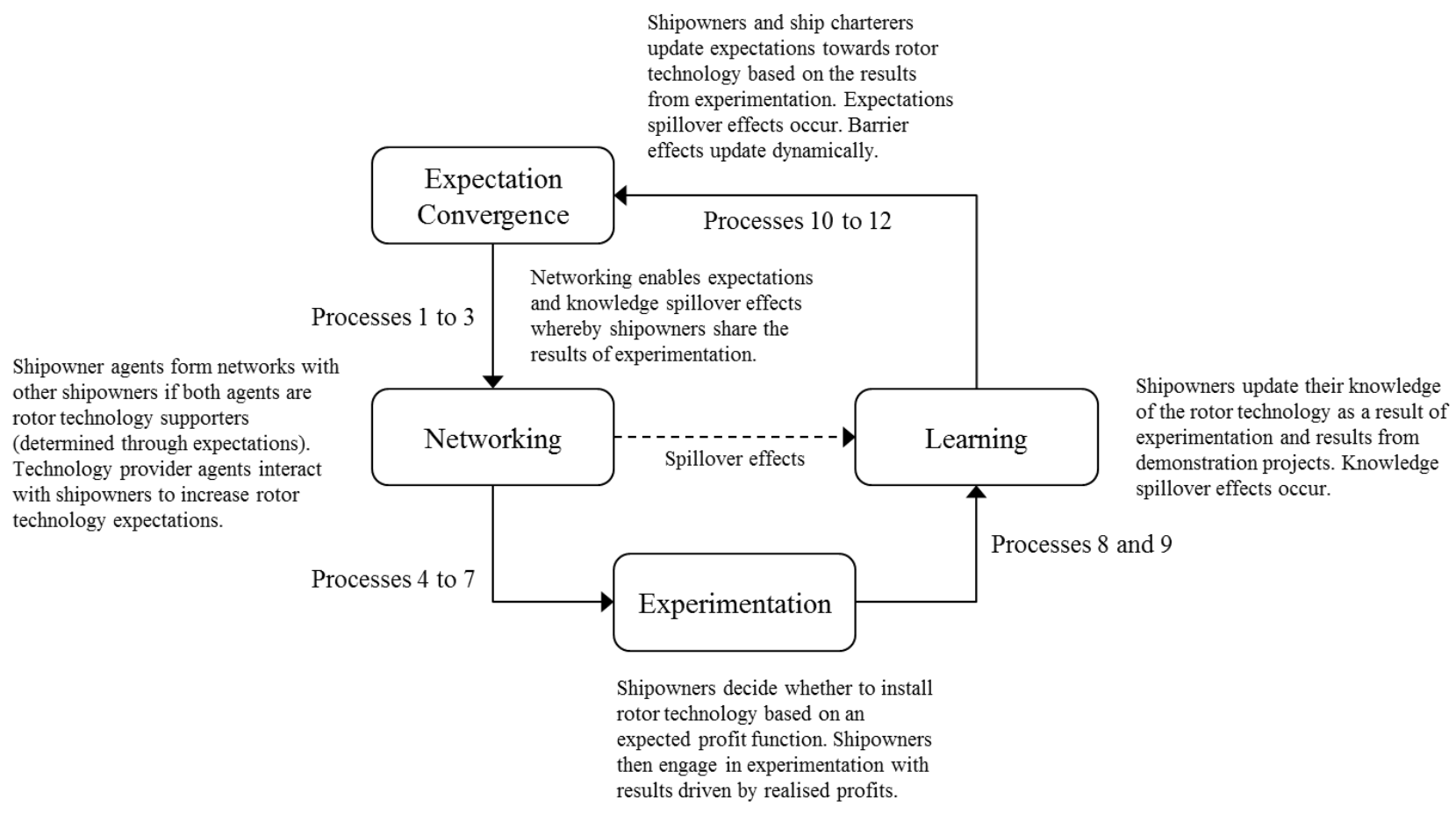

Figure 1 Niche model dynamics (adapted from Lopolito et al. (2013))

\subsubsection{Process 1: Period setup}

In each period technical risk is reflected in the grid through the random allocation of grey cells with a probability determined by the Risk variable (Lopolito et al., 2013). The use of grey cells in the wrapped grid is a simple and transparent mechanism to model the random impact of rotor technology failure (either through user error or design) on shipowner profits, as perceived by shipowners and technology providers (Rehmatulla et al., 2017b). Technical risk for rotor technology includes ship structural integrity and stability, and cargo handling issues. It is assumed that rotor technologies are homogenous and operational best practice is widely shared, so that technical risk (the probability of being present on a grey cell) is the same for each shipowner. Shipowners that are present in the same grid cell will experience simultaneous technology failure. Market risks are assumed constant, so all ships are chartered each period. Once technical risk is calculated, shipowner agents 'move' 2.5 cells in a random direction within the two-dimensional wrapped grid. Over time, these shipowners begin to network (Lopolito et al., 2013).

\subsubsection{Process 2: Networking between shipowners}

Shipowner expectations $\left(E X_{i, t}\right)$ in relation to rotor technology performance range from 0 (no interest) to 1 (complete preference). If expectations are greater than the threshold value $\left(E X_{\text {support }}\right)$, the shipowner stops being a regime supporter and joins the network of niche supporters (Lopolito et al., 2013). The niche network facilities knowledge spill-over effects; the shipowners share the results from experiments with rotor technology with other shipowners connected by a direct link within the 
niche network, and increase rotor technology knowledge (Process 8) and shipowner expectations towards the rotor technology (Process 12).

\subsubsection{Process 3: Shipowner interaction with technology providers}

Technology providers interact with, and increase the expectations of regime shipowners that have not adopted the wind propulsion technology. Expectations are not directly observable and therefore the increase in expectations due to technology providers is one of three calibrated model parameters. Once regime shipowner expectations $\left(E X_{i, t}\right)$ towards rotor technology exceed 0.5 , the shipowner becomes a niche supporter. Niche supporter expectations cannot be increased above this threshold through interactions with technology providers. This mechanism represents the significance of imperfect information and the need for shipowners to validate technology provider claims (Nelissen et al., 2016; Rehmatulla et al., 2017b).

\subsubsection{Process 4: Shipowner fuel costs}

Shipowner $i$ calculates ship fuel cost $\left(F_{i, t}\right)$ for period $t$ in millions of dollars $(\$ \mathrm{~m})$. This fuel cost is paid by the time charterer and includes any associated carbon pricing costs.

\subsubsection{Process 5: Shipowner decision to install rotor technology}

The shipowners use the Expected Net Present Value or $E(N P V)$ metric to decide whether they will install rotor technology (Rehmatulla et al., 2015, Nelissen et al., 2016). The $E(N P V)$ is calculated from the shipowner's expected incremental profits in \$m from a chartered ship fitted with rotor technology over the discounted payback period of $T$ months (equation 1) where $D R$ is the discount rate assumed $(8.5 \%)$ (Nelissen et al., 2016) and $E\left(K_{t}^{n}\right)$ the capital cost of fitting the rotor technology. If $E(N P V)$ is greater than zero the rotor technology is adopted.

$E(N P V)=\sum_{t=1}^{T} \frac{E\left(F P T_{i, t}^{n}\right)-E\left(C^{n}\right)}{(1+D R)^{t}}-E\left(K_{t}^{n}\right)$

Incremental revenues to the shipowner $i\left(F P T_{i, t}^{n}\right)$ from niche technology adoption capture the fuel cost savings from its use that are passed from the charterer to shipowner through an increased charter premium (Ådland et al., 2016; Raucci et al., 2017). The expected incremental shipowner revenues $\left(E\left(F P T_{i, t}^{n}\right)\right)$ are a function of: the monthly ship fuel cost $\left(F_{i, t}\right)$, the expected percentage fuel saving from rotor technology $(E(R E))$, charterer expectations of rotor technology effectiveness $\left(E X_{C, t}\right)$ calculated as average shipowner expectations for the period, and shipowner expectations $\left(E X_{i, t}\right)$ to 
reflect technology performance uncertainty (Lopolito et al., 2013). ${ }^{4}$ This formulation represents the risk averse nature of the shipping industry. $E\left(F P T_{i, t}^{n}\right)$ is given by:

$E\left(F P T_{i, t}^{n}\right)=\left(F_{i, t} \times E(R E) \times E X_{C, t}\right) \times E X_{i, t}$

The parameter $E(R E)$ represents the promises of technology providers in relation to rotor technology performance, and it is assumed constant to simplify the model. ${ }^{5}$ Variable shipowner and charterer expectations result in a dynamic calculation of expected incremental shipowner revenues from rotor technology. $E X_{C, t}$ represents the charterers perception of rotor technology performance, a factor they consider when they set their premiums (Smith et al., 2013b, p.77). The parameter $E X_{C, t}$ corresponds to the barrier factor in Raucci et al. (2017) and captures the split incentives barrier in this model. The lower the charterer expectations towards rotor technology, the smaller the fuel savings proportion from rotor technology that the charterer passes on to the shipowner. The shipowner incurs the capital expenditure for the rotor technology, and therefore has a lower economic incentive to install the technology as per equation 1 .

It is assumed that charterers have homogenous expectations and do not participate directly in niche experiments. Instead they take cues from shipowner expectations towards rotor technology energy efficiency and its reliability. The expected additional maintenance cost to the shipowner from rotor technology adoption, denoted by $E\left(C_{i, t}^{n}\right)$, is calculated using a modified formula from Lopolito et al. (2013), ${ }^{6}$ whereby costs are multiplied by 2 minus the shipowner's expectations given by:

$E\left(C_{i, t}^{n}\right)=C_{i, t}^{n} \times\left(2-E X_{i, t}\right)$

In equation 3 , shipowners with zero expectations overestimate costs by $100 \%$. The expected revenues and costs capture the importance of performance uncertainty on shipowner investment decisions and are analogous to the imperfect information barrier. Shipowners estimate the capital $\operatorname{cost} E\left(K_{t}^{n}\right)$ of adopting the rotor technology through equation 4 :

$E\left(K_{t}^{n}\right)=K_{t}^{n} \times\left(2-E X_{i, t}\right)$

In addition to the $E(N P V)$ test (equation 1), shipowners require the rotor technology to generate an incremental operational profit. The expected operational profit when using regime technologies depends on the difference between shipowner charter revenues $R_{i, t}^{R}$ and operational costs $C_{i, t}^{R}$, which are assumed to be constant. The incremental operational profit from using the niche rotor technology depends on the expected incremental revenues from rotor technology, $E\left(F P T_{i, t}^{n}\right)$, minus the expected

\footnotetext{
${ }^{4}$ This formulation captures the risk averse nature of the shipping industry towards new technologies. Further work could explore different formulations of this expectations mechanism.

${ }^{5}$ This assumption is a limitation of the current model formulation as the expected fuel savings from rotor technology could increase as experimentation occurs. The authors chose the mid-point of simulated data from Nelissen et al. (2016) as a simplifying assumption. The authors would like to thank a reviewer for raising this issue.

${ }^{6}$ The original equation 5 in Lopolito et al. (2013) is: $E\left(C_{i, t}^{n}\right)=C_{i, t}^{n} \times \frac{1}{E X_{i, t}}$.
} 
incremental costs from rotor technology adoption, $E\left(C_{i, t}^{n}\right)$. The expectation mechanisms in equations 3 and 4 are again applied to the possible incremental rotor revenues and incremental maintenance costs from the rotor technology installation. Regime revenues and costs are not considered uncertain as they represent the current financial position of shipowners before rotor technology is adopted and are therefore not subject to expectation mechanisms. It is assumed that the drybulk time charter regime is perfectly competitive and that regime profits are nil (Ådland et al., 2016). Therefore, an incremental operational profit from rotor technology usage signals to shipowners an improvement in overall ship profitability. The operating profit test is passed if the expected incremental operating profit from rotor technology usage to supplement regime propulsion, $E\left(O P_{i, t}^{n}\right)$, is greater than regime operating profits. Essentially, there is an expected incremental profit from rotor technology.

$$
E\left(O P_{i, t}^{n}\right)=\left(R_{i, t}^{R}-C_{i, t}^{R}\right)+E\left(F P T_{i, t}^{n}\right)-E\left(C_{i, t}^{n}\right)
$$

\subsubsection{Process 6: Shipowners determine whether to 'use' rotor technology}

The niche supporters repeat the operational profit condition test in subsequent periods to ensure the technology remains profitable. Shipowners can remove or stop rotor usage if their expectations fall due to failed experiments and change from an expected operating profit to an expected loss. It is assumed that shipowners leave the equipment necessary to re-install rotor technology on their ships (for example, mountings), so that if the operating profit condition is satisfied and if expectations improve in future periods, shipowners can resume rotor technology niche experiments.

\subsubsection{Process 7: The realised operating profits of shipowners in a period}

The realised (as opposed to expected) shipowner operational profit $\left(O P_{i, t}^{n}\right)$ is calculated in each period. If a shipowner occupies a grey cell the profit calculation is assumed to exclude $F P T_{i, t}^{n}$ revenues due to rotor technology 'failure', with an associated claim (Claim) for underperformance made by the charterer (Veenstra and Van Dalen, 2011). If rotor technology operates as expected, realised shipowner profits $O P_{i, t}^{n}$ equal $F P T_{i, t}^{n}$ revenues minus rotor operational costs. $O P_{i, t}^{n}$ for shipowner $i$ in period $t$ is given by:

$$
O P_{i, t}^{n}=\left\{\begin{array}{l}
\left(\left(R_{i, t}^{R} \times(1-\text { Claim })\right)-C_{i, t}^{R}\right)-C_{i, t}^{n} \\
\left(R_{i, t}^{R}-C_{i, t}^{R}\right)+F P T_{i, t}^{n}-C_{i, t}^{n}
\end{array}\right\} \begin{aligned}
& \text { with probability } P \\
& \text { with probability } 1-P
\end{aligned}
$$

Where realised revenues from rotor technology are given by:

$$
F P T_{i, t}^{n}=\left(F_{i, t} \times R E_{i, t} \times E X_{C, t}\right) \times E X_{i, t}
$$

The realised fuel efficiency savings from the rotor technology $\left(R E_{i, t}\right)$, are calculated as a percentage of fuel costs randomly selected from a gamma distribution with shape parameter $\alpha=6$ and rate 
parameter $\beta=23.7 .{ }^{7}$ This approach captures the uncertainty and variability of wind propulsion which depends on wind conditions, and therefore the variability of shipowner revenues (FPT). This approach reflects a commercial structure whereby FPT revenues are adjusted according to actual wind conditions and therefore actual fuel savings.

\subsubsection{Process 8: Shipowners update knowledge through experiments}

Shipowners learn about the technical performance, user requirements, barriers to use, and the rotor technology's infrastructure compatibility through rotor technology experiments. Each shipowner experiment increases the knowledge stock $\left(K N_{i}\right)$ of that shipowner $i$ through the parameter $K N_{\text {incr }}$. Shipowner experiments also have a spillover effect which increases the knowledge of those shipowners with a direct link to the experimenting shipowner within the niche network. Each time period the knowledge of shipowners with a direct link to the experimenting shipowner is increased by an amount equal to $K N_{\text {incr }}$ (the increase in knowledge of the experimenting shipowner) multiplied by $K N_{\text {spillover }}$ (a factor equal to 0.25 ), to reflect imperfect knowledge transfer between shipowners. In each time period, the knowledge increase for each shipowner due to the spillover effect is equal to $K N_{\text {totalspillover }}$, which is the sum of the knowledge spillovers from each experimenting shipowner with a direct link to the shipowner. Equation 8 shows how the knowledge for a shipowner increases each time period through two effects: direct experimentation $\left(K N_{\text {incr }}\right)$ and indirect spillover effects $\left(K N_{\text {totalspillover }}\right)$.

$$
K N_{i, t+1}=K N_{i, t}+K N_{\text {incr }}+K N_{\text {totalspillover }}
$$

\subsubsection{Process 9: Shipowner interactions with demonstration projects}

Demonstration projects are set to run from $t=1$ for a specified number of months. The demonstration project operates within the grid, and moves a defined distance each period in a random direction. The demonstration projects increase the expectations and knowledge of shipowners within a defined radius $\left(D_{\text {radius }}\right)$ on the grid from the demonstration project. The increase in expectations and knowledge of shipowners within this radius is defined by the $D_{\text {EXincr }}$ and $D_{K N i n c r}$ parameters. $D_{\text {radius }}$ is set at 3 which represents moderate dissemination of project results from an institutional project to shipowners. It is assumed that demonstration projects can only increase shipowner expectations to $D_{E X \max }$, set at 0.75 to reflect the importance of direct experimentation and validation within the niche supporter network. Furthermore, it is assumed that demonstration projects, once implemented, are successful and therefore cannot decrease shipowner expectations toward the rotor

\footnotetext{
${ }^{7}$ Calculated from data provided by M. Traut from Delft - data from the Nelissen et al. (2016) paper.
} 
technology. ${ }^{8}$ This is an important model simplification. Further research is required to examine the importance of demonstration project design and risk associated with negative results (either minor, or a major technological or operational failure). ${ }^{9}$

\subsubsection{Process 10: Technical risk update}

Rotor technology Risk decreases with an increase in shipowner knowledge $\left(K N_{i, t}\right)$, and represents the cumulative result of experiments of the niche supporter network and knowledge acquired from demonstration projects. The average of $K N_{i, t}$ represents a balance between improvements in technical risk driven through the niche shipowners' interactions with technology providers and infrastructure owners, and improvements that reflect a greater understanding by shipowners of 'best practice' within the niche. The result is that technical risk follows an inverted s-shaped curve (Geroski, 2000) and is given by:

$$
\operatorname{Risk}_{t+1}=\operatorname{Risk}_{t}-\left(\frac{\sum_{i=1}^{n} K N_{i}}{n} \times\left(\frac{R^{2} s k_{t}}{\text { Risk }_{t=0}}\right)\right)
$$

\subsubsection{Process 11: Rotor technology capital costs}

It is assumed that a doubling of installed capacity, or ships using rotor technology, results in a percentage reduction ( $L R)$ in rotor technology capital cost (Rubin et al., 2015; Nelissen et al., 2016). This learning rate is set to $10 \%$ in line with other shipping models (Nelissen et al., 2016) and renewable technologies such as wind turbines which are considered similar to rotor technologies (Rubin et al., 2015). Demonstration agents are counted as an additional installed unit to calculate the installed capacity for the learning curve effect.

\subsubsection{Process 12: Shipowners (and charterers) update expectations}

Shipowner expectations $\left(E X_{i, t+1}\right)$ are updated through the realised operational profit (or loss) $\left(O P_{i, t}^{n}\right)$ from niche experiments:

$$
E X_{i, t+1}=E X_{i, t}+O P_{i, t}^{n}
$$

The operational profit (or loss) of shipowner neighbours in the network from experiments with rotor technology, creates expectation spillover effects that increase (or decrease) shipowner expectations (Rogers, 2003). This approach is similar to the mechanism used to calculate knowledge spillover effects. This impact is reduced through the application of a factor, $E X_{\text {spillover }}$. This approach again reflects imperfect information and the importance of direct expectation. The expectations of

\footnotetext{
${ }^{8}$ Note the impact of the demonstration project is separate to the result of shipowner experimentation where operating profits can be negative, harming shipowner expectations.

${ }^{9}$ The authors would like to thank a reviewer for drawing further attention to this issue.
} 
shipowners that do not use rotor technology also experience small random movements that reflect socio-technical landscape variation and industry speculation (equation 11):

$$
E X_{i, t+1}=E X_{i, t}+\left(V_{i, t}-0.025\right)
$$

Where $V_{i, t}$ is a random number from 0 to 0.05 under a uniform distribution. Charterer expectations $\left(E X_{C, t+1}\right)$ are recalculated (equation 12) with the updated average shipowner expectations for the start of the next period. Charterer expectations are used in equation 2 to capture the split incentives barrier. The split incentives barrier and its impact on diffusion becomes dynamic, rather than a fixed parameter, as charterer expectations are updated in each model period.

$$
E X_{C, t+1}=\frac{1}{n} \sum_{i=1}^{n} E X_{i, t+1}
$$

The model then updates outputs such as charts and counters, and loops back to process 1 and moves to the next period.

\subsection{Model parameterisation and empirical validation}

Parameterisation and empirical validation ensures that an ABM provides a realistic simplification of the simulated system. The ABM literature identifies the following approaches:

Table 1: Approaches to parameterisation and empirical validation

\begin{tabular}{cl}
\hline Source & \multicolumn{1}{c}{ Approaches } \\
\hline \multirow{2}{*}{ Windrum et al. (2007) } & • Indirect calibration \\
& • Werker-Brenner \\
\hline Thiele et al. (2014) & • Best-fit \\
& • Categorical calibration \\
\hline
\end{tabular}

The Werker-Brenner approach is followed for model calibration and validation (Werker and Brenner, 2004; Windrum et al., 2007). The few parameters for which empirical data was not available were calibrated against the Bass diffusion curve from Rehmatulla et al. (2015). The result is that the model within this paper will produce results similar to those in Rehmatulla et al. (2015) once the split incentive and imperfect information barriers are turned off, meaning the model can be used to evaluate the impact of these two barriers on rotor diffusion. Figure 2 demonstrates the model can replicate key stylised facts from the diffusion literature once barriers are turned off (see Appendix A for calibration and validation details). 


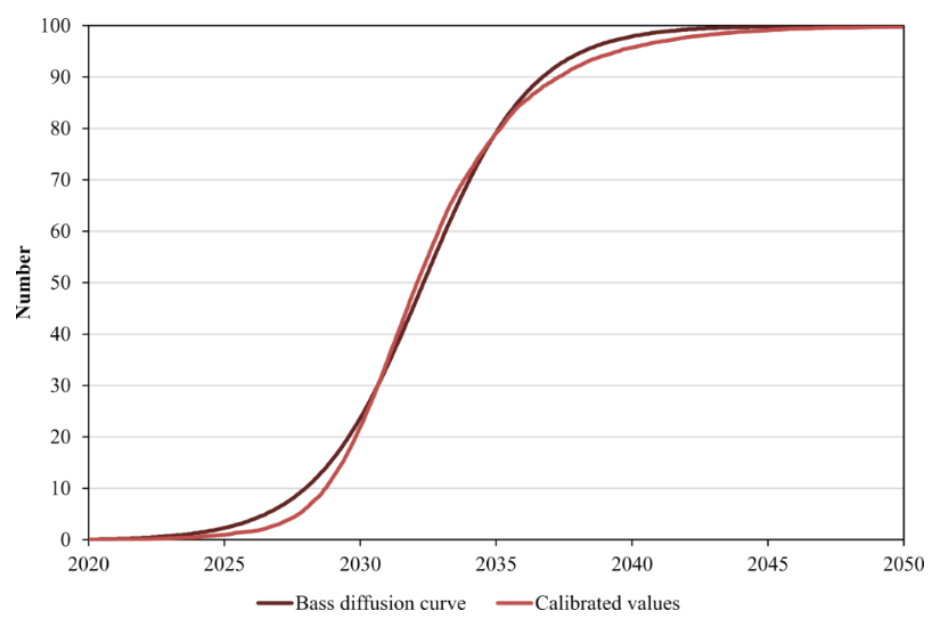

Figure 2 Model calibration against the Bass diffusion curve from Rehmatulla et al. (2015)

Table 2 provides model parameters, initial values specific to the shipping industry, and sources. Empirical data was used where available from the shipping literature for initial parameterisation (Werker and Brenner, 2004) (see Appendix B for all model parameters). ${ }^{10,11}$

Table 2 Selected reference baseline scenario parameters

\begin{tabular}{|c|c|c|c|}
\hline Parameter & Value & Description & Source \\
\hline Risk $_{t}$ & 0.25 & Risk of a technical failure. & Author's assumption. \\
\hline$E X_{i, t}$ seeded & 0.75 & $\begin{array}{l}\text { Expectations towards rotors for } 5 \text { niche } \\
\text { supporters seeded at } t=0\end{array}$ & See footnote for author's assumption. \\
\hline$E X_{i, t}$ regime & 0.175 & $\begin{array}{l}\text { Expectations towards rotors of the regime } \\
\text { actors at } t=0\end{array}$ & See footnote for author's assumption. \\
\hline EX $X_{\text {support }}$ & 0.5 & $\begin{array}{l}\text { Expectations threshold at which niche } \\
\text { actors become niche supporters. }\end{array}$ & $\begin{array}{l}\text { Author's assumption; consistent with } \\
\text { Lopolito et al. (2013) approach. }\end{array}$ \\
\hline$T P_{\text {EXincr }}$ & 0.15 & $\begin{array}{l}\text { Increase in shipowner expectations from } \\
\text { technology provider interaction. }\end{array}$ & Calibrated. \\
\hline Frons $_{i}$ & 560 & Fuel consumption in mt per month. & $\begin{array}{l}\text { 2009-2011 mean fuel consumption for } \\
60,000-99,999 \text { dwt bulk carrier from Smith } \\
\text { et al. (2014) excluding boom periods } \\
\text { (̊̊dland et al., 2016). }\end{array}$ \\
\hline Fprice $_{t}$ & $400-800$ & LSHFO price in $\$ / \mathrm{mt}$. & $\begin{array}{l}\text { Raucci et al. (2017) and author's } \\
\text { assumptions: see Figure } 3 \text {. }\end{array}$ \\
\hline Fcarbon & 3.114 & $\begin{array}{l}\mathrm{CO} 2 \text { emitted in mt per mt of fuel } \\
\text { consumed. }\end{array}$ & Smith et al. (2014). \\
\hline$D P_{\text {hurdle }}$ & 60 & $\begin{array}{l}\text { Discounted payback hurdle assumption } \\
\text { (months). }\end{array}$ & Nelissen et al. (2016). \\
\hline$C^{n}$ & 0.0125 & $\begin{array}{l}\text { Rotor technology maintenance cost in } \$ \mathrm{~m} \\
\text { per month. }\end{array}$ & $\begin{array}{l}\text { Technology provider data reported in } \\
\text { Rehmatulla et al. (2017b). }\end{array}$ \\
\hline
\end{tabular}

${ }^{10}$ Author assumption; limited data is available on actual shipowner expectations towards rotor technology. Assuming seeded niche supporters expectations are high (0.75), regime actor expectations are set to provide an average charterer expectation of $20 \%$ at $\mathrm{t}=0$, reflecting a small increment on the $14 \%$ charter premium for an energy efficient Panamax drybulk vessel in Ådland et al. (2016). The increment assumes improving sentiments towards energy efficiency to 2020. The resulting low regime expectations (0.175) seem reasonable given the risk-averse nature of the industry (Rojon and Dieperink, 2014) and limited rotor technology implementation (Rehmatulla et al., 2017b).

${ }^{11}$ Within this paper Step 3 is not performed and the single set of parameter values identified in Step 2 forms the focus of analysis. Note that if this model is to be used to inform policy design, future research must first explore whether alternative plausible model formulations exist. 


\begin{tabular}{|c|c|c|c|}
\hline$K^{n}$ & 2 & $\begin{array}{l}\text { Rotor technology initial capital cost in } \\
\$ \mathrm{~m} .\end{array}$ & GloMEEP (2017). \\
\hline$E(R E)$ & 0.25 & $\begin{array}{l}\text { Expected (mean) fuel savings from using } \\
\text { rotor technology on the Long Beach to } \\
\text { Shanghai route. }\end{array}$ & $\begin{array}{l}\text { Nelissen et al. (2016); simulation data for } \\
\text { a } 90,000 \text { dwt bulk carrier on Long Beach } \\
\text { to Shanghai route. }\end{array}$ \\
\hline$E X_{C, t}$ & 0.2 & Charterer expectations. & $\begin{array}{l}\text { For } t=1 \text {, calculated for subsequent time } \\
\text { periods. }\end{array}$ \\
\hline$D R$ & 0.085 & Shipowner investment discount rate. & Nelissen et al. (2016). \\
\hline$R_{i, t}^{R}$ & 0.304 & Regime time charter rate per month in \$m. & Raucci et al. (2017); \$10,000/day. \\
\hline$C_{i, t}^{R}$ & 0.304 & $\begin{array}{l}\text { Perfect competition assumed for drybulk } \\
\text { regime, therefore } R_{i, t}^{R}=C_{i, t}^{R} \text {. }\end{array}$ & Ådland et al. (2016). \\
\hline Claim & 0.25 & $\begin{array}{l}\text { Proportion of charter revenues claimed by } \\
\text { charterer in case of technical failure. }\end{array}$ & $\begin{array}{l}\text { Author's assumption reflecting } 25 \% \text { time } \\
\text { lost during the month. }\end{array}$ \\
\hline$R E_{i, t}$ & $0.08-0.52$ & $\begin{array}{l}\text { Actual fuel savings from using rotor } \\
\text { technology on the Long Beach to } \\
\text { Shanghai route; a random number selected } \\
\text { from a gamma distribution with } \alpha=6 \\
\text { and } \beta=23.7 \text {. }\end{array}$ & $\begin{array}{l}\text { Distribution calculated from fuel saving } \\
\text { percentage data used within Nelissen et al. } \\
\text { (2016) and sourced from the authors } \\
\text { directly. }\end{array}$ \\
\hline$K N_{i}$ & $0 / 0.01$ & Shipowner rotor technical knowledge. & $\begin{array}{l}\text { Author's assumption; seeded niche } \\
\text { supporters have initial endowment. }\end{array}$ \\
\hline$K N_{\text {incr }}$ & 0.05 & $\begin{array}{l}\text { Increase in rotor technical knowledge } \\
\text { from experimentation. }\end{array}$ & $\begin{array}{l}\text { Author's assumption; lower model } \\
\text { sensitivity therefore not calibrated. }\end{array}$ \\
\hline$K N_{\text {spillover }}$ & 0.25 & $\begin{array}{l}\text { Rotor technical knowledge spillover to } \\
\text { network neighbours as proportion } \\
\text { of } K N_{\text {incr }} \text {. }\end{array}$ & $\begin{array}{l}\text { Author's assumption; lower model } \\
\text { sensitivity therefore not calibrated. }\end{array}$ \\
\hline$L R$ & 0.1 & Rotor capital cost learning rate. & Nelissen et al. (2016); Rubin et al. (2015) \\
\hline EX $X_{\text {spillover }}$ & 0.075 & $\begin{array}{l}\text { Shipowner expectations spillover to } \\
\text { network neighbours as proportion of } O P \\
\text { profit (or loss) for month. }\end{array}$ & Calibrated. \\
\hline$N$ & 100 & Number of shipowners. & Author's assumption. \\
\hline Speed $_{i}$ & 2.5 & Shipowner 'speed'. & $\begin{array}{l}\text { Author's assumption; lower model } \\
\text { sensitivity therefore not calibrated. }\end{array}$ \\
\hline$T P$ & 2 & Number of technology providers. & $\begin{array}{l}\text { Author's assumption; reflects low } \\
\text { numbers of technology providers within } \\
\text { Nelissen et al. (2016) relative to } \\
\text { shipowner propulsion. }\end{array}$ \\
\hline Speed $_{T P}$ & 5 & Technology provider 'speed'. & $\begin{array}{l}\text { Author's assumption; lower model } \\
\text { sensitivity therefore not calibrated. }\end{array}$ \\
\hline$S Y$ & 1 & Number of shipyards. & $\begin{array}{l}\text { Author's assumption; lower model } \\
\text { sensitivity therefore not calibrated. }\end{array}$ \\
\hline Speed $_{S Y}$ & 1.25 & Shipyard 'speed'. & $\begin{array}{l}\text { Author's assumption; lower model } \\
\text { sensitivity therefore not calibrated. }\end{array}$ \\
\hline$S Y_{\text {radius }}$ & $1-5$ & $\begin{array}{l}\text { Radius within which shipowners can } \\
\text { install rotor technology. }\end{array}$ & $\begin{array}{l}\text { Author's assumption; scales through } \\
\text { shipowner expectations. }\end{array}$ \\
\hline
\end{tabular}

\subsection{Simulation scenarios}

Table 3 presents the parameters that were used to model carbon price and demonstration project scenarios. 
Table 3 Parameter values for carbon price and demonstration project scenarios

\begin{tabular}{|c|c|c|c|}
\hline Parameter & Value & Description & Source \\
\hline Cprice $_{t}$ & $0-200$ & Carbon price in $\$ / \mathrm{mtCO}_{2}$. & $\begin{array}{l}\text { Consistent with range used within } \\
\text { Raucci et al. (2017); range deemed } \\
\text { reasonable. }\end{array}$ \\
\hline$D_{\text {EXincr }}$ & 0.0025 & $\begin{array}{l}\text { Increase in shipowner expectations } \\
\text { due to demonstration per month }\end{array}$ & Calibrated. \\
\hline$D_{E X \max }$ & 0.75 & $\begin{array}{l}\text { Limit to expectations increase from } \\
\text { demonstration project. }\end{array}$ & $\begin{array}{l}\text { Author's assumption; reflecting } \\
\text { importance of experimentation. }\end{array}$ \\
\hline$D_{\text {KNincr }}$ & 0.0025 & $\begin{array}{l}\text { Increase in shipowner rotor technical } \\
\text { knowledge due to demonstration per } \\
\text { month. }\end{array}$ & $\begin{array}{l}\text { Author's assumption; lower model } \\
\text { sensitivity therefore not calibrated, } \\
\text { set to small amount due to frequent } \\
\text { shipowner interactions. }\end{array}$ \\
\hline$D_{\text {period }}$ & 180 & $\begin{array}{l}\text { Demonstration project duration in } \\
\text { months. }\end{array}$ & $\begin{array}{l}\text { Author's assumption; equivalent to } \\
\text { short investment horizon ( } 15 \text { years) } \\
\text { in Raucci et al. (2017). }\end{array}$ \\
\hline$D_{\text {radius }}$ & 3 & $\begin{array}{l}\text { Radius within which shipowners } \\
\text { interact with demonstration project. }\end{array}$ & Author's assumption. \\
\hline Speed $_{D}$ & 1.25 & $\begin{array}{l}\text { Demonstration project 'speed' in } \\
\text { social space; denotes rate of } \\
\text { interaction with shipowners. }\end{array}$ & Author's assumption. \\
\hline
\end{tabular}

Table 4 presents the scenario values for carbon price and the number of demonstration projects. Scenario 1 represents a baseline without policies implemented (Strachan, 2011) that excludes possible interactions with the Energy Efficiency Design Index and Ship Energy Efficiency Management Plan which are outside the model scope. Figure 3 presents the base fuel price assumption ('mid') together with a low and a high sensitivity.

Table 4 Carbon price and demonstration project scenarios

\begin{tabular}{clll}
\hline No. & \multicolumn{1}{c}{ Scenarios } & Carbon price & Demonstration Project(s) \\
\hline 1 & Reference Baseline & - & - \\
2 & $\$ 50 / \mathrm{mtCO}_{2}$ & $\$ 50 / \mathrm{mtCO}_{2}$ & - \\
3 & Demonstration Project & - & 1 project (180 months) \\
4 & Combined Policies & $\$ 50 / \mathrm{mtCO}_{2}$ & 1 project (180 months) \\
\hline
\end{tabular}

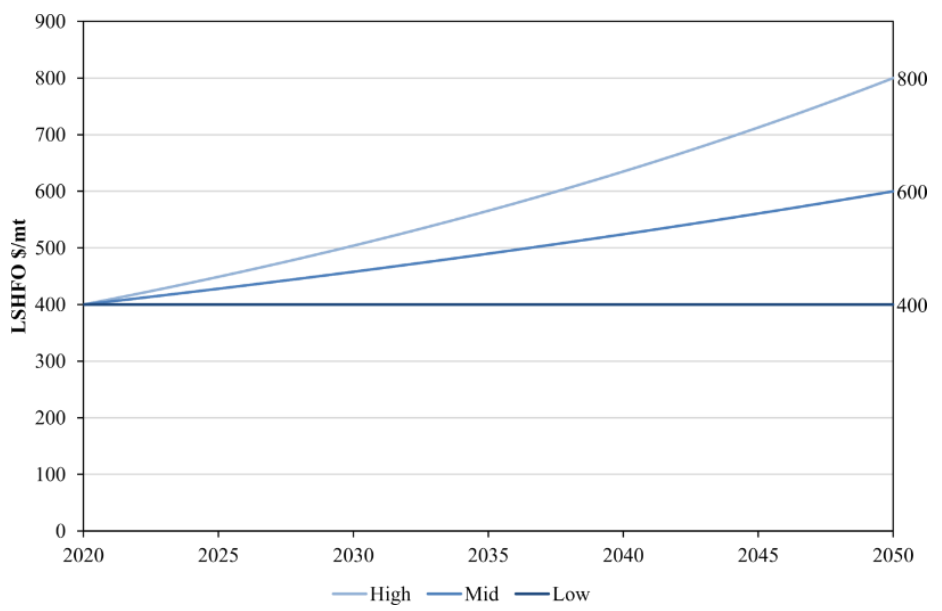

Figure 3 Fuel price assumptions (source: Raucci et al. (2017) and author assumptions) 


\subsection{Model results}

Each set of results reflects the average for 100 shipowners over 100 model runs. Figure 4 shows how users, supporters, and strong supporters change over time under each scenario. The introduction of a low carbon price $\left(\$ 50 / \mathrm{mtCO}_{2}\right)$ increases the cost of fuel which improves the economic benefit from rotor technology installation, and results in limited diffusion where $22 \%$ of shipowners use rotor technology in 2050 (Figure 4, top right). This late, gradual diffusion reduces total 2020-2050 $\mathrm{CO}_{2}$ emissions by $0.4 \%$ against the Reference Baseline scenario (Figure 4 , top left). In the demonstration project scenario, the number of niche supporters rises until the project ends in 2035 (Figure 4, bottom right). At this point, the expectations towards the rotor technology remain below the threshold required for niche supporters to view the technology as economic (due to the imperfect information barrier). Rising fuel prices eventually lend support and make rotor technology sufficiently economic for strong supporters to begin the cycle of experimentation, learning, expectations convergence, and networking outlined in Figure 1. Once this diffusion feedback loop begins to operate, the number of supporters and users grows rapidly.
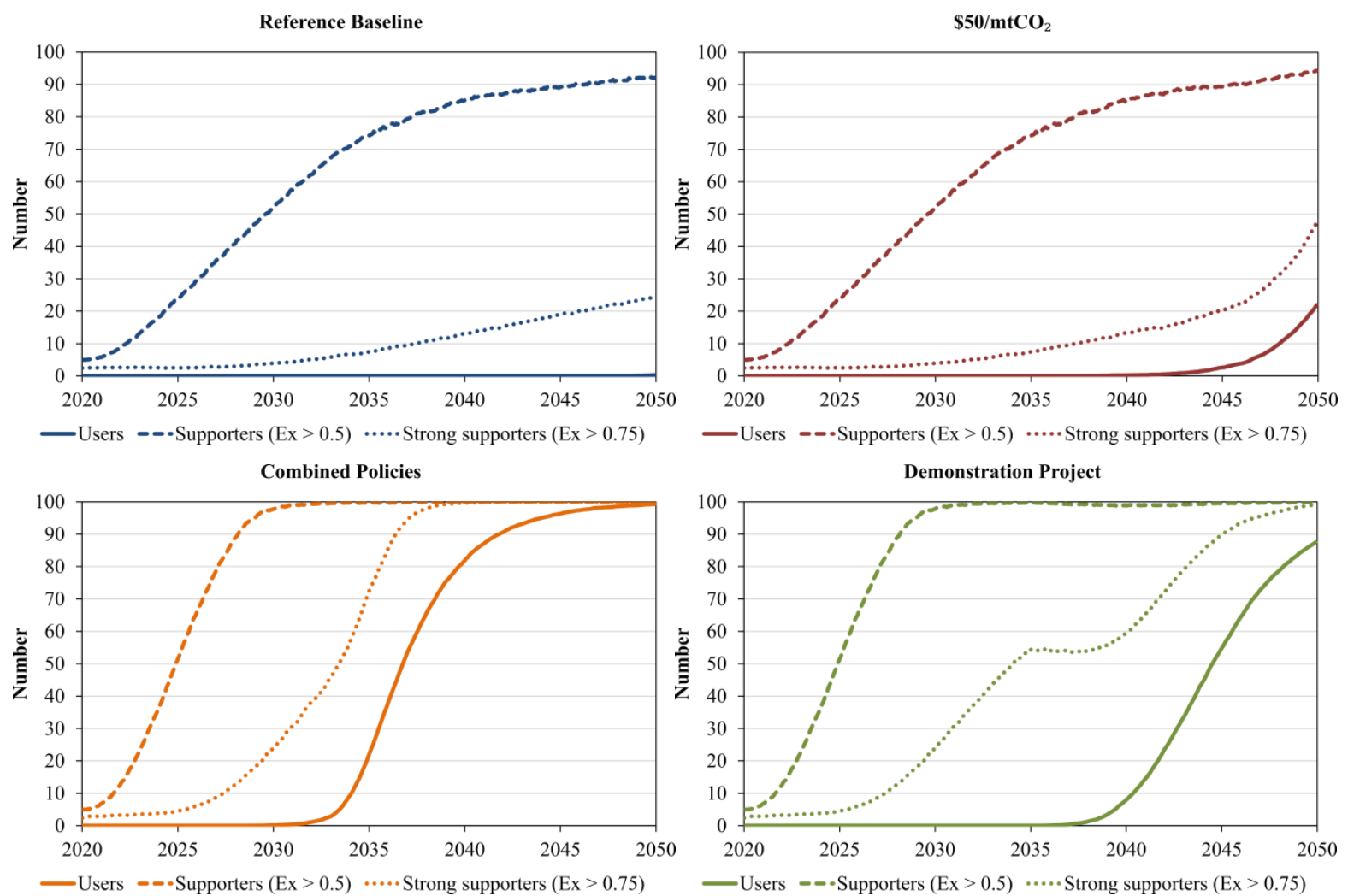

Figure 4 Users, supporters, and strong supporters for scenarios 1-4 from top left, clockwise

Figure 5 (top left) compares user numbers between scenarios. The introduction of a 180-month demonstration project is more effective than carbon pricing, with $88 \%$ adoption of rotor technology by 2050 (Figure 5, green line) and a $4.4 \% \mathrm{CO}_{2}$ emission reduction in 2050 relative to the Reference Baseline scenario. 
Figure 5 (top left) summarizes the average number of users under the scenarios in Table 4 and the rest of the figures illustrate results with $95 \%$ intervals. Figure 5 (top right) shows results for the $\$ 50 / \mathrm{mtCO} 2$ scenario where diffusion is driven by economic incentives created by the carbon price and rising fuel prices. Shipowner expectations drive the variation in results, subject to stochastic mechanisms within the model. Figure 5 (bottom right) presents results for the Demonstration Project scenario which starts diffusion in 2035 . The subsequent rise in fuel prices renders the rotor technology economic for a larger number of shipowners than under the $\$ 50 / \mathrm{mtCO}_{2}$ scenario, where the diffusion is more gradual and more dependent on individual shipowner expectations. This outcome, together with the plateau in strong supporters seen in Figure 4 (bottom left) suggests that a more stochastic approach for modelling the Demonstration Project(s) should be explored in future work. This figure shows that a demonstration project implemented in isolation could result in a wide range of possible outcomes. Most diffusion results fall within the 75-100\% range by 2050. Figure 5 shows the impact on variation with combined policies. The carbon price means that the economic threshold for rotor technology is reached before the plateau in strong supporters seen under the Demonstration Project scenario. The combination of economic support from the carbon price and stronger expectations growth from the demonstration project drives more rapid diffusion. The narrow spread of results under the Combined Policies scenario suggests that the combination of policies could result in reduced uncertainty and more robust diffusion of rotor technology.

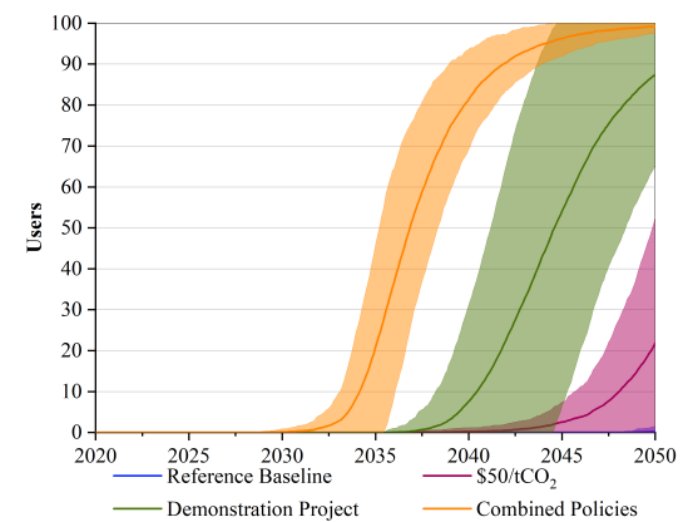

Figure 5 Total number of users under the scenarios in Table 4 with 95\% intervals

Figure 6 demonstrates the effect of fuel price variation on user numbers. Diffusion is sensitive to fuel price and demonstrates why shipowners identify fuel price uncertainty as a significant barrier to investment (Rehmatulla et al., 2017b). For example, if fuel prices remain flat at $\$ 400 / \mathrm{mt}$ (the low fuel price assumption), even with carbon price support, rotor technology remains uneconomic for strong supporters (Figure 6, top right). In addition, the strong diffusion from the demonstration project also depends on fuel price rise, without which no diffusion occurs (Figure 6, bottom right). It should be noted that diffusion occurs even under the low fuel price assumption when these policies are 
combined (Figure 6, bottom left). This result again indicates that the policy combination is more robust than either policy introduced in isolation.
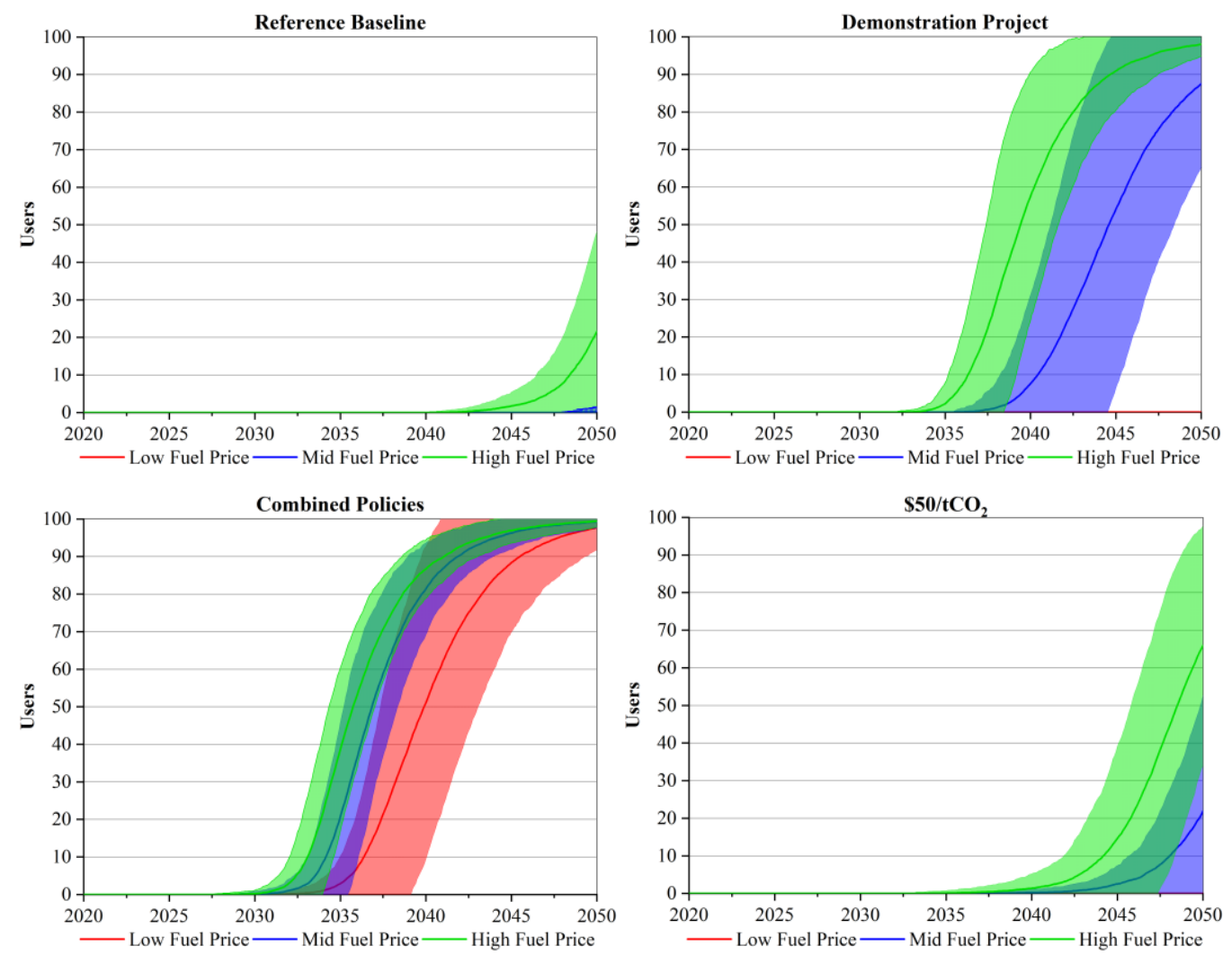

Figure 6 Users under different fuel price assumptions for scenarios 1-4 from top left, clockwise

Figure 7 presents results for average shipowner expectations (left), and technical risk (right). The demonstration project drives shipowner expectations up to 0.75 (Figure 7, left). When the demonstration project stops in 2035, the average shipowner expectations remain flat as the positive feedback from experimentation has still not commenced. Increased expectations reduce the impact of barriers and increase expected shipowner profits from rotor technology but not to an extent where shipowner experimentation begins spontaneously. With average shipowner expectations around 0.75 , a rise in fuel price is still required for rotor technology to make economic sense.

Average shipowner expectation levels are similar between the Reference Baseline (blue line) and $\$ 50 / \mathrm{mtCO}_{2}$ (red line) scenarios until experimentation commences around 2040 (Figure 7, left). Then, rising prices and the additional carbon price support make rotor technology viable for shipowners who install it and trigger the positive feedback between experimentation, learning, and shipowner expectations. This feedback is supported by learning effects which reduce capital costs. Experiments provide information about technology performance and reduce imperfect information. This increases shipowner expectations and improves expected rotor technology profits, increasing charterer expectations and reducing the split incentives barrier. The expectations growth rate increases (Figure 7, left) as learning reduces technical risk (Figure 7, right) which further increases 
shipowner profits from experimentation (Figure 8, left). Falling barriers drive rotor diffusion amongst "early adopters" and further improve rotor economic performance through continuous positive feedback.
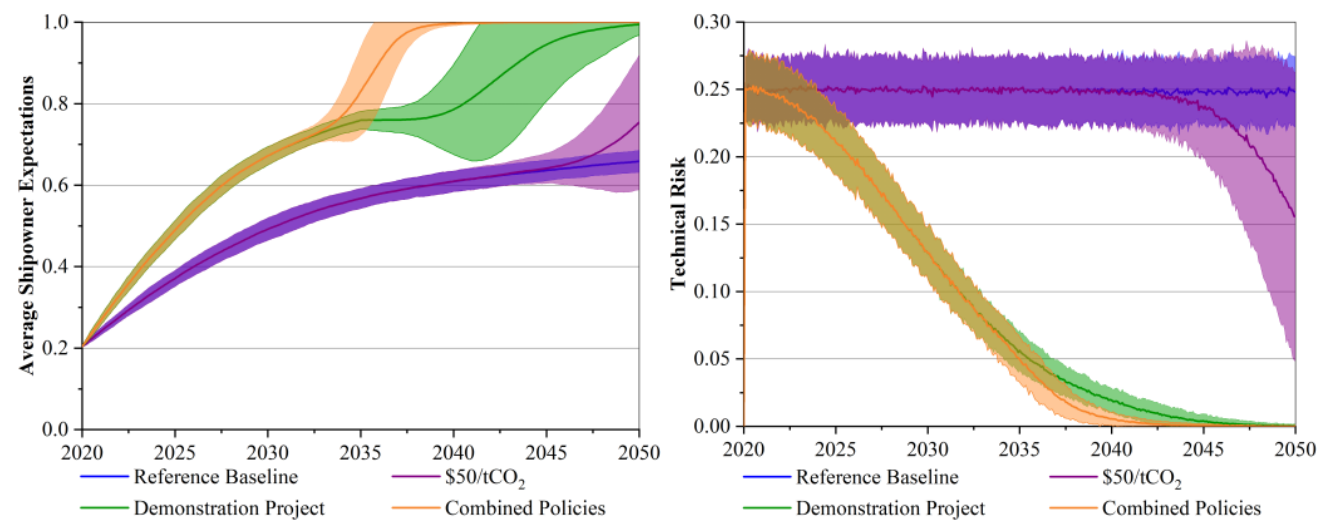

Figure 7 Average shipowner expectations per scenario (left), technical risk per scenario (right)

Figure 8 (left) illustrates the operational profits that can become negative with experimentation failures across the four scenarios. The total $\mathrm{CO}_{2}$ emission reduction during 2020-2050 with rotor technology provides a clear performance metric for policy (Figure 8, right). The theoretical maximum represents the $\mathrm{CO}_{2}$ emission reduction that could be achieved if all 100 shipowners used rotor technology from $\mathrm{t}=0$ on the Long Beach to Shanghai route (see Nelissen et al., 2016).

A $\$ 50 / \mathrm{mtCO}_{2}$ carbon price policy has limited impact on rotor diffusion and reduces $\mathrm{CO}_{2}$ emissions from shipowners by $0.4 \%$ to 2050 . The demonstration project is more effective, with earlier, stronger rotor diffusion and $4.4 \% \mathrm{CO}_{2}$ emissions reduction by 2050 . In both policy cases, the role of fuel prices is instrumental. High or rising fuel prices are important for wind propulsion diffusion (Rojon and Dieperink, 2014; Mander, 2017; Rehmatulla et al., 2017b).

The policy combination of a carbon price and the demonstration project is more effective in overcoming barriers, with strong rotor diffusion from 2030, that reaches almost $100 \%$ of shipowners in 2050 (Figure 4, bottom right), and achieves a 10.6\% $\mathrm{CO}_{2}$ emission reduction by 2050 (Figure 8, right), more than double the sum of both policies implemented separately (4.8\%). The policy combination is also more robust to lower fuel prices. If fuel prices remain flat at $\$ 400 / \mathrm{mt}$, then initial rotor diffusion is delayed by only 5 years but still approaches $100 \%$ in 2050 , and $\mathrm{CO}_{2}$ emission reductions decrease to $8.1 \%$ from $10.6 \%$. 

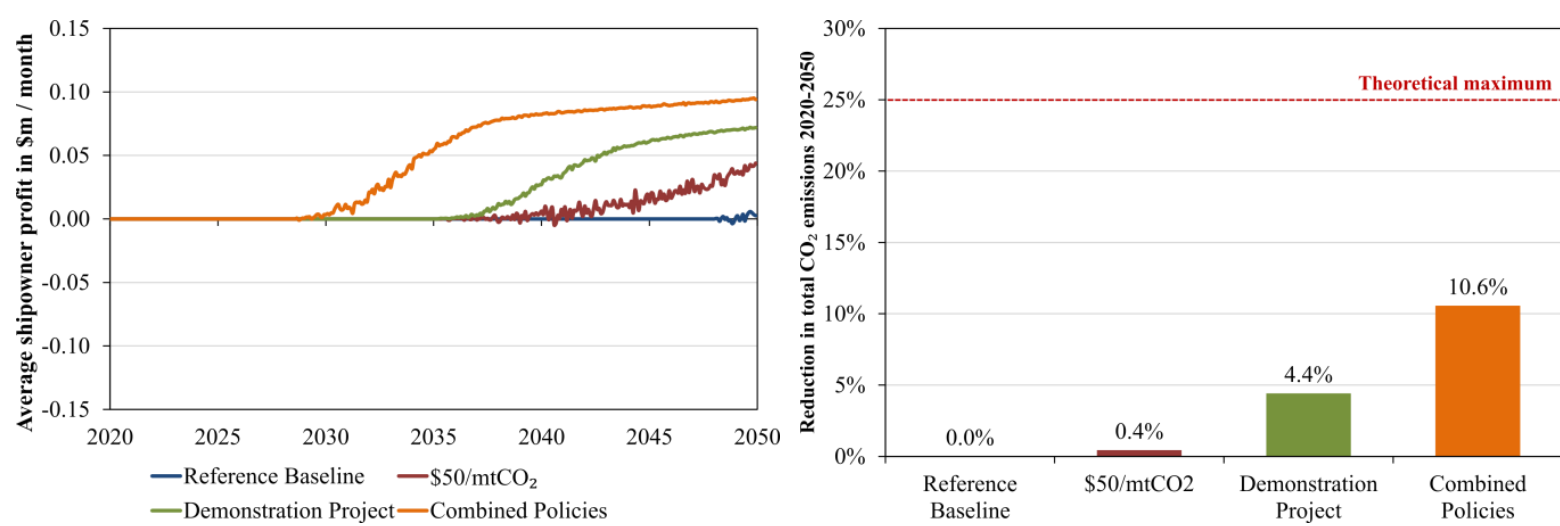

Figure 8 Average shipowner profit (left), estimated reduction in total $\mathrm{CO}_{2}$ emissions (right) for the four scenarios

\subsection{Sensitivity analysis}

Sensitivity analysis is performed on carbon price, the number and duration of demonstration projects, and the shipping route wind conditions. Figure 9 (left) shows $\mathrm{CO}_{2}$ emissions reductions for different combinations of carbon price and numbers of demonstration projects. The first demonstration project delivers significant, incremental reductions in $\mathrm{CO}_{2}$ emissions for the carbon price range of $\$ 50$ 200/mtCO 2 (Figure 9, left). The incremental impact of both carbon pricing and demonstration projects diminishes as the carbon price or number of demonstration projects is increased. This is consistent with results in Eide et al. (2011) where incremental $\mathrm{CO}_{2}$ emissions savings diminish for abatement costs greater than $\$ 100 / \mathrm{mtCO}_{2}$. Instead of many demonstration projects, a focus on a few welldesigned ones might prove most effective as it minimises the risk of failure and improves their feasibility given their cost (Nelissen et al., 2016). The duration of demonstration projects has a significant impact on $\mathrm{CO}_{2}$ reduction at carbon prices below $\$ 100 / \mathrm{mtCO}_{2}$ (Figure 9 , right). Information and learning spillover effects are assumed to be gradual in the model, so the longer the duration, the greater the impact on the split incentives and imperfect information barriers, and the greater corresponding emission reduction.
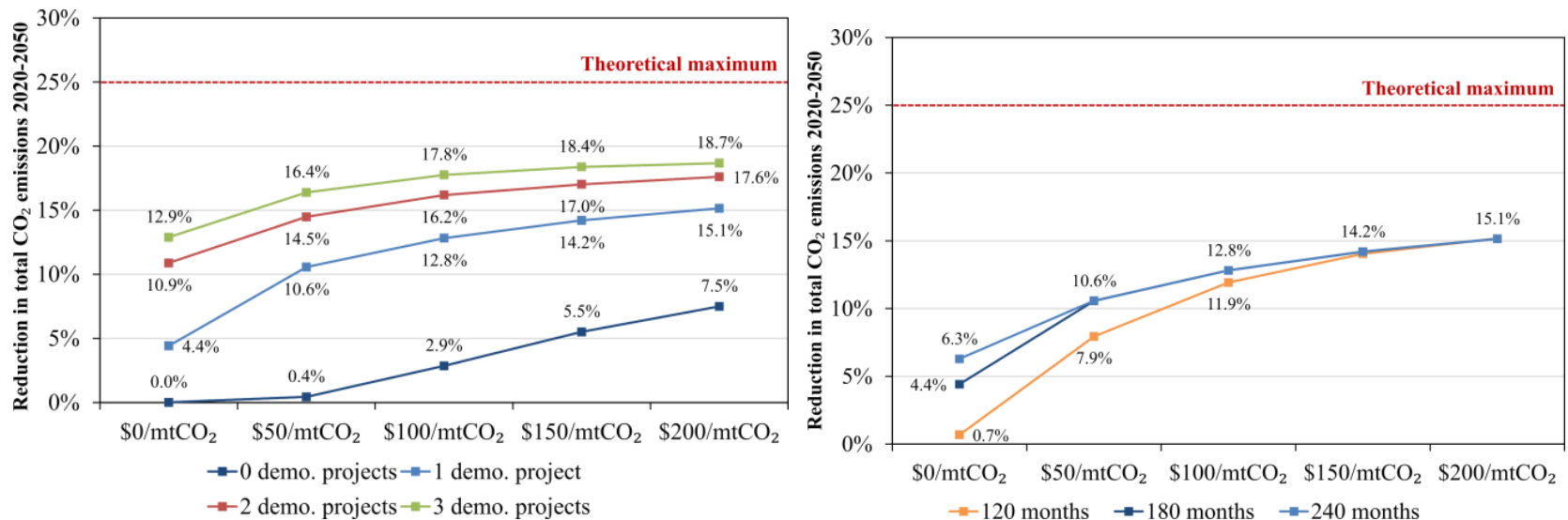

Figure 9 Emission reduction sensitivity to carbon price and number of demonstration projects (left), emission reduction sensitivity to carbon price and demonstration project duration (right). 
The model was also run with wind data from a route with lower wind potential; Rotterdam to Shanghai (Nelissen et al., 2016). A combination of high carbon price $\left(\$ 200 / \mathrm{mtCO}_{2}\right)$ and multiple demonstration projects is required to achieve even modest, total $\mathrm{CO}_{2}$ emission reductions (3.5-4.7\%) (Figure 10, left). These results are in agreement with literature for the critical role of wind favourable routes for wind technology adoption. Such routes are passive protective spaces which allow technological experimentation and learning which reduces barriers and costs (Senger and Köhler, 2015; Mander, 2017).

The estimated carbon price required to pass the discounted payback test given average shipowner expectations was calculated (Figure 10, right) with a simple discounted cash flow model assuming charterer expectations equal shipowner expectations with expected fuel saving data on the favourable Long Beach to Shanghai route $(25 \%)$ and the Rotterdam to Shanghai route (10\%). The results suggest that the carbon price required for rotor diffusion on a route with poor wind potential would not be feasible from both a political and economic perspective. However, knowledge spillover from niche experimentation on routes with favourable wind conditions to routes with less favourable conditions could reduce the technical risk and capital cost involved, improve agent expectations, and thus move the required carbon price into a more politically feasible range (see the red dashed line in Figure 10, right).
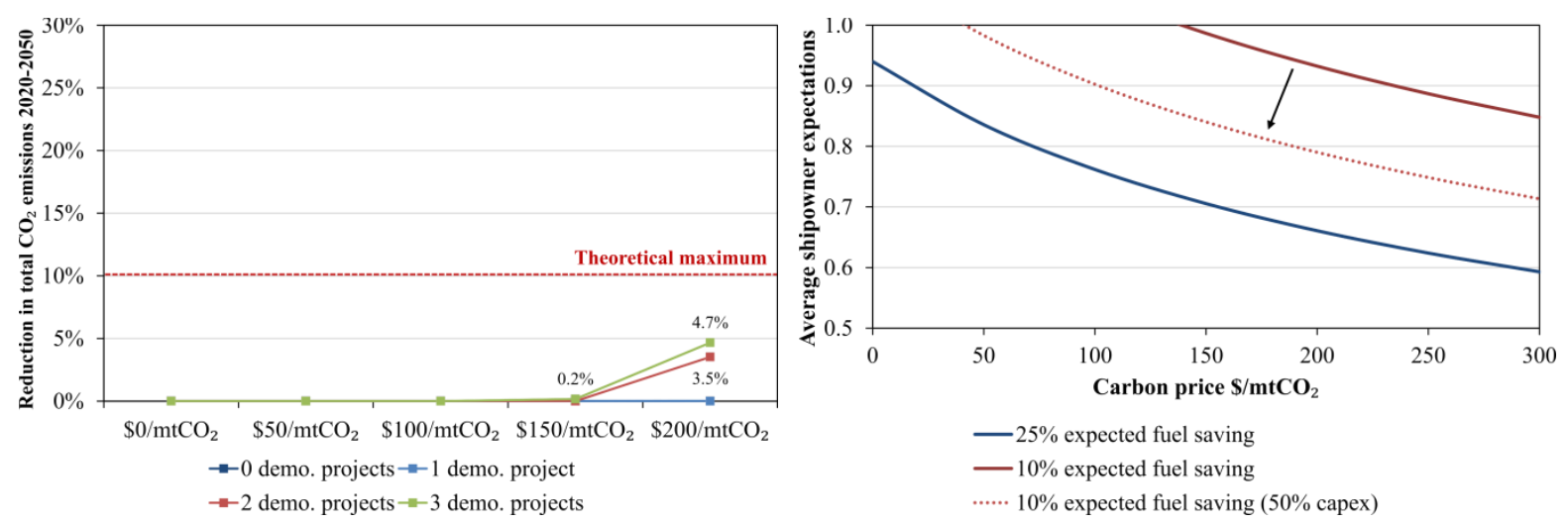

Figure 10 Sensitivities on ship route with poor wind conditions (left), average shipowner expectations and the discounted payback test (right)

Figure 11 compares the results for the combined policies outlined in Figures 4 to 10 with those obtained from switching off the split incentives barrier. Diffusion without the split incentives barrier occurs early from 2020 and approaches saturation around 2030 to 2035 in agreement with Nelissen et al. (2016). Diffusion with the split incentives barrier in place, delays until 2030 and approaches saturation around 2045. This result illustrates that barriers do not just impact the diffusion rate but also the timing of initial diffusion, adding to the insights in Rehmatulla et al. (2015). 


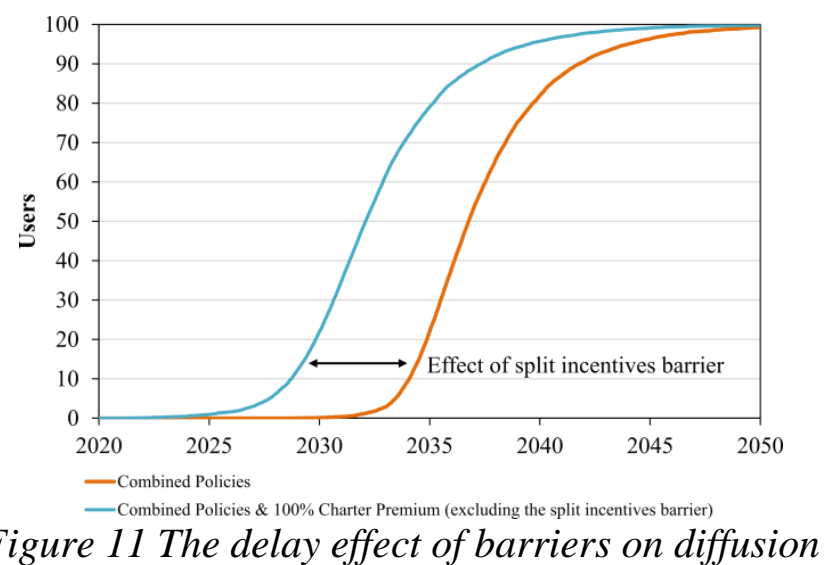

\section{Discussion}

\subsection{The effect of incentives}

The imperfect information and split incentives barriers could constrain significantly the rotor adoption by shipowners in the period to 2050, even on routes with favourable wind conditions. Technology provider interactions with shipowners increase their expectations $\left(E X_{i, t}\right)$, and it is assumed that once shipowner expectations reach 0.5, any further increase requires experimentation, or exogenous socio-technical landscape changes such as fuel prices increases to increase rotor technology attractiveness to shipowners and charterers alike.

The base fuel price assumption in the model assumes a gradual increase in fuel prices from $\$ 400 / \mathrm{mt}$ in 2020 to $\$ 600 / \mathrm{mt}$ in 2050 (Figure 3). This increase represents a pressure on the incumbent regime from the socio-technical landscape and increases the expected fuel savings for rotor technology. Shipowner expectations gradually increase with fuel prices but are not enough to trigger experimentation even for strong rotor technology supporters. Shipowners underestimate the expected rotor technology profits due to imperfect information and charter premiums for rotor technology remain poor due to split incentives. Limited charter premiums, and low fuel costs and expectations, lead shipowners to perceive rotor technology as uneconomic. Adoption remains low, which limits learning, and keeps capital costs high. The imperfect information and split incentives barriers prevent diffusion through blocking the positive feedback loop between experiments, learning, and expectations (Figure 1).

The results in this paper contrast with those in Rehmatulla et al. (2015) which suggest that barriers only slow the rate of diffusion, rather than block or prevent diffusion altogether. The results in this paper are more conservative than results in Nelissen et al. (2016) which consider all routes, with a constant bulk fleet size at 2020 levels, and under similar modelling assumptions, suggest that perhaps $80 \%$ of bulk carriers might use wind propulsion in 2030 . The difference between results in in this paper and in Nelissen et al. (2016) is partially attributable to the rapid diffusion of wind 
propulsion technologies in the Nelissen et al. (2016) model. ${ }^{12}$ The difference in results demonstrates that the omission of barrier and expectation mechanisms from techno-economic models could generate optimistic diffusion forecasts.

In this paper, it is assumed that carbon price influences shipowner expectations through improvements in rotor economic performance and increased experiment participation. The $\$ 50 / \mathrm{mtCO}_{2}$ carbon price increases charterer fuel costs and makes rotor economic performance more attractive to shipowners, even when the percentage of fuel cost savings passed to them is kept constant. This demonstrates that financial instruments such as a carbon price can help mitigate the split incentives barrier. Fuel price increases represent 'windows of opportunity' for the niche innovation to increase its market share (Schot and Geels, 2008). This emphasizes the importance of carbon prices or policy instruments that provide financial support for rotor diffusion until experimentation begins and positive feedbacks can further reduce barriers. Without this support a demonstration project might be less effective (Figure 6, bottom right) through delayed positive feedback or reliance on economic support from factors outside the control of policy makers such as socio-technical landscape pressures in the form of rising oil prices.

A key underlying assumption for these results is that demonstration project failures cannot reduce shipowner expectations. ${ }^{13}$ It is assumed that learning accumulates each period from an active demonstration project and increases shipowner expectations. Catastrophic failures, such as the loss of a vessel and/or life, are not considered within this model. In reality a public failure might significantly reduce industry expectations towards a niche technology or result in the extinction of a niche supporter network completely.

Knowledge accumulation from demonstration projects reduces rotor technical risk from 2020 (Figure 7, right). Rising fuel prices then encourage innovators to install the rotor technology, project results are more positive due to the lower technical risk, which then increases shipowner expectations and rotor diffusion compared to the $\$ 50 / \mathrm{mtCO}_{2}$ scenario. These findings suggest that diffusion might accelerate if shipowners are provided with incentives for early experimentation with rotor technology through direct public funding (Nelissen et al., 2016) as industry expectations could benefit from the earlier positive feedback, assuming that results are positive. However, corporate interests and market competition might render this approach implausible.

The $\$ 50 / \mathrm{mtCO}_{2}$ carbon price reduces the expectation threshold of shipowners for rotor technology adoption through rotor technology improvements in profitability relative to conventional propulsion. The demonstration project increases the percentage of fuel cost savings passed to

\footnotetext{
${ }^{12}$ Diffusion rates under the Nelissen et al. (2016) model are more consistent with those presented below once barriers are removed from the model within this paper (see Figure 11).

${ }^{13}$ Note the important distinction between the institutional demonstration project policy and shipowner experimentation.
} 
shipowners through increasing expectations, and further reduces the expectations threshold required for shipowner experimentation. The end result is that shipowner experimentation occurs earlier. The reduced technical risk from the demonstration project (Figure 7, right) and the economic support from the carbon price generate much higher initial realised rotor profits from experimentation (Figure 8, left), that accelerate positive feedback, reduce barriers more quickly, and make diffusion occur earlier and at a faster rate.

The model results show that the combination of policies is significantly more effective and robust for rotor adoption and $\mathrm{CO}_{2}$ emissions reduction than the introduction of either policy in isolation. This result is in agreement with more general conclusions from the wider energy literature (Grubb, 2014). Such policy combinations may also be equally effective for other energy efficiency technologies, other shipping sectors, and perhaps other industries, depending on technology attributes (Rogers, 2003; Rehmatulla et al., 2015). The results of the policies explored in this model provide an indication as to their effectiveness, but they are not forecasts for wind propulsion diffusion in shipping as the model has a number of important simplifications.

\subsection{Transition pathways}

The simulation results in sections 3.4 and 3.5 provide insight into the adoption of an alternative propulsion technology within shipping and its impact on emissions. The broader shipping transition could unfold along several MLP transition pathways (Geels and Schot, 2007). The diffusion of wind propulsion within shipping currently appears to follow a transformation pathway as landscape pressures are moderate or low and the application of wind propulsion in shipping niches is not yet mature. Landscape pressures in shipping are low to moderate but they grow; the recent IMO Sulphur 2020 regulations require a significant reduction in permissible sulphur oxide emissions from shipping by January 2020. These regulations will exert additional economic pressure on shipowners through an increase in fuel costs, an example of evolutionary dynamics.

In addition, wind propulsion technologies for modern freight vessels are immature niche innovations that develop through small scale experiments and are not common in the wider shipping industry. However, regime actors (the shipowners in this case) may start to use their adaptive capacity to modify the direction of shipping technology development in response to changes in the selection environment. Maersk Tankers, Norsepower, The Energy Technologies Institute, and Shell have recently begun trialing Flettner rotor technology on a 109,647dwt product tanker. This application represents a symbiotic, competence enhancing add-on technology to conventional propulsion technologies in the shipping regime (Geels and Schot, 2007).

However, shipping is a heterogeneous industry that operates on routes with different environmental conditions. This variety could favour different combinations of conventional and 
alternative propulsion technologies. Variations on technical solutions will appear, some of which will have a better fit with the selection environment (for example, particular shipping routes with favourable wind conditions). If technologies have symbiotic relationships with the regime, they can be adopted as add-ons or through replacing components, driven by economic considerations and improved performance, whilst leaving most regime rules unchanged. Alternative propulsion technologies such as sails are not a new idea technically and thus are not, in isolation, disruptive to the regime. Knowledge about their use in a modern context will need to be developed as an add-on to the incumbent shipping regime and ship designs, with initially only minor modifications to the regime. However, over time the alternative propulsion technologies will mature and drive deeper, more fundamental adjustments in the regime's basic architecture. For example, in contract structures, regulations, port infrastructure, operations management, navigation technologies, and vessel design. This is the point where the transition may follow a reconfiguration pathway as innovations initially adopted to solve specific problems, may eventually enable major changes in the basic architecture of the regime (Geels and Schot, 2007), with possible implications for other regimes and sociotechnical systems outside shipping.

\subsection{Limitations and future research}

The model results in this paper should be considered in the context of the underlying assumptions, as providing insights rather than precise projections. The assumptions of charterer expectations and the split incentives barrier, and the impact of demonstration projects have been modelled in a simple and transparent manner to facilitate tractability. Building of this initial model foundation, further development of mechanisms for dynamic charterer expectations or demonstration projects could provide deeper insights into the adoption of alternative propulsion technologies in shipping. In addition, it should be noted that further model refinement could also be performed through Step 3 of the Werker-Brenner (2004) approach; an abductive process whereby alternative model specifications, each of which might also represent a good fit with real observable data, are compared and the most plausible configuration selected.

This model assumes 100 shipowners each with a single ship. This model formulation does not permit detailed exploration of how shipowners might benefit from learning and increasing returns to scale from installing alternative propulsion technologies on several ships. ${ }^{14}$ Such dynamics could potentially accelerate the diffusion of alternative technologies or lead to large jumps in diffusion and imply that current model results are conservative. The effect of increasing returns to scale is an issue

\footnotetext{
${ }^{14}$ The authors would like to thank a reviewer for raising this issue.
} 
for further research that would require expansion of the model to include fleet level decisions capturing the rollout of a proven profitable technology from a single ship across the shipowner's fleet.

Industry heterogeneity has been identified as a barrier in shipping (Rehmatulla et al., 2017b). The model could be expanded in future research to reflect company and fleet sizes, new ship designs, access to capital, or different shipping routes. Technical change in the incumbent regime could be modelled to include 'sailing ship effects' (Ward, 1967). Moreover, the model could account for potential rebound effects that arise from ship energy efficiency improvements, with charterers using energy efficiency as a competitive advantage (Berkhout et al., 2000; Rehmatulla and Smith, 2015). Some studies dismiss the rebound effect in shipping (Buhaug et al., 2009).

The paper aimed to demonstrate the importance of expectations mechanisms and barriers for the shipping sector transition to alternative propulsion technologies. Future research should consider how these mechanisms might be integrated with current techno-economic models, already rich in industry detail. Furthermore, the effect of expectations on the diffusion of propulsion technologies is shown to be instrumental and future research could explore the development of an 'expectations' metric for shipping actors using survey data. Institutional demonstration projects were shown to be an important policy. Further research could consider the possible impact of poorly designed experiments on diffusion and explore how modelling can inform the design of such projects to maximise effectiveness and minimise the risk of failure.

Further model development could extend its application to explore the diffusion of other energy efficiency technologies or explore diffusion within other shipping sectors. The model could explore multiple competing wind propulsion technologies and assess whether certain technologies can emerge as a "dominant design", or whether several technologies emerge per application domain. More broadly it could be modified and applied to other industries that face similar issues to shipping such as aviation (Schäfer et al., 2016).

\section{Conclusions}

Carbon emissions from international shipping are expected to increase significantly in line with global trade trends. It is imperative that the shipping industry follow the trajectories of other industries and reorient towards a low carbon trajectory. Several ship propulsion technologies can reduce shipping $\mathrm{CO}_{2}$ emissions but they face innovation barriers that potentially limit their diffusion. For example, in time charter contracts, ship charterers cover their fuel costs whilst shipowners cover other operational and capital costs that include investments in energy efficient technologies. The result is that shipowner incentives to invest in energy efficiency measures and reduce fuel costs for charterers are low because the potential increase in their revenues from higher time charter rates are limited. Policies 
to overcome such barriers include carbon pricing, and demonstration projects which publish results in the public domain.

The paper aims to explore the effect of policies on the shipping transition. A transitions perspective is adopted to analyze the diffusion of Flettner rotor technology in time charter drybulk shipping. An agent-based model is developed based on Lopolito et al. (2013; 2014), to explore the effect of policies on $\mathrm{CO}_{2}$ emissions. The model results show that the combination of $\$ 50 / \mathrm{mtCO}_{2}$ carbon price and demonstration projects is much more effective relative to either policy introduced separately. In the model, the combination of policies reduces $\mathrm{CO}_{2}$ emissions by approximately $10 \%$, more than double the aggregate result of either policy implemented separately (4\%), and more than a $\$ 200 / \mathrm{mtCO}_{2}$ carbon price (7\%). The policy combination is also more robust to low fuel prices, consistent with wider recommendations for energy policy design (Grubb, 2014). Furthermore, barriers are shown to impact both the rate and timing of rotor diffusion.

The model results in this paper indicate that additional policies are required to overcome the imperfect information and split incentives barriers that could prevent the diffusion of rotor technology in drybulk shipping in the period to 2050, significantly reducing emissions reductions. This result is in agreement with literature on key shipping industry barriers. The results demonstrate that the omission of these barriers from techno-economic shipping models leads to overestimation of the current decarbonisation potential of the sector.

Sensitivity analysis shows that carbon price and the number of demonstration projects face diminishing returns in $\mathrm{CO}_{2}$ emission reductions. The greatest reduction occurs from the initial demonstration project combined with a politically and economically feasible carbon price $\left(\$ 50 / \mathrm{mtCO}_{2}\right)$. Under lower carbon price assumptions, reducing the duration of the demonstration project reduces significantly rotor adoption and corresponding emissions reductions. A carbon price above $\$ 100 / \mathrm{mtCO}_{2}$ in combination with multiple demonstration projects has limited incremental benefit. High carbon prices combined with multiple demonstration projects are required for even limited diffusion to occur on routes with poor wind conditions. This result confirms the importance of passive protective spaces for the emergence of niche wind propulsion technologies. The diminishing returns to demonstration project numbers suggest that focus should be placed on the design of a few realistic and high-quality demonstration projects. Industry should be consulted during the design of such projects to ensure that results are accepted by industry. Industry acceptance is key to drive up expectations towards rotor technology and reduce possible experimental failures that might delay diffusion.

These results suggest that a cost-effective policy to increase the learning and diffusion rates of rotor technology and reduce the need for carbon price support, would be to focus initially on routes with more favourable wind conditions that form naturally protected innovation niches. Shipowners 
that operate on routes with less favourable wind conditions will benefit from learning, reduced barriers and lower costs. The improvement in rotor performance from this initial learning and experimentation in a protected innovation niche would drive more rapid global diffusion. Shipping is heterogeneous and separate demonstration projects might be required for each sector and technology pairing e.g. kites in the container sector or sails in the tanker sector. It should be noted that lessons learned might be specific to certain sectors should key sectoral or technological characteristics be unique. 


\section{Appendix: Calibration}

The Werker-Brenner approach is a three-step method for the empirical calibration and validation of simulation models (Werker and Brenner, 2004; Windrum et al., 2007). Step 1 requires that model parameters are calibrated using micro-level real-world empirical data where available. Step 2 requires the comparison of macro-level real-world observations to model results obtained from running multiple model specifications (or different parameter values for key parameters) in order to calibrate and validate the model. Step 3 requires that the parameter values with a good fit to real world observations be compared through an abductive process, resulting in a single final set of parameter values. Within this paper Step 3 is not performed and the single set of parameter values identified in Step 2 forms the focus of analysis. If this model is to be used to provide detailed insights into policy design, future research must first explore whether alternative plausible model formulations exist.

The $T P_{\text {EXincr }}, E X_{\text {spillover }}$, and $D_{\text {EXincr }}$ parameters are calibrated using the Werker-Brenner approach since the model is sensitive to these parameters and no empirical data could be obtained within Step 1. There is no micro-level empirical data available for these three parameters due to the somewhat qualitative nature of user expectations towards a technology, combined with the lack of diffusion of wind propulsion technologies in shipping. Rehmatulla et al. (2015) use the Bass diffusion model framework to analyse the installation of pre/post swirl devices and Mewis Duct technologies to estimate coefficients of innovation (0.001) and imitation (0.5) for the diffusion of energy efficient technologies within shipping (Table 2 in Rehmatulla et al. (2015)); this data is used as a proxy for the possible diffusion of wind propulsion technologies within shipping.

Assumptions underlying the calibration model should be consistent with those used to generate the diffusion curve within Rehmatulla et al. (2015). The Bass diffusion model (Bass, 1969) does not consider the split incentives barrier mechanism; therefore, for calibration purposes only, we disable this in the model and all fuel cost savings from rotor technology are assumed to be fully passed on to shipowners. Other calibration assumptions include a demonstration project from 2020. This is a proxy for the lower imperfect information barriers apparent for the pre/post swirl devices or Mewis Duct technologies used to calibrate the Bass diffusion curve (these technologies are more easily installed due to lower cost and their viability subsequently demonstrated). The carbon price is set at $\$ 50 / \mathrm{mtCO}_{2}$, consistent with the low assumption within Raucci et al. (2017). The Reference Baseline price assumption is used.

Model calibration was performed using 125 separate model specifications formed from combinations of the three calibration parameters outlined in Table A.1. The choice of only three calibration parameters whilst holding other parameters constant represents a consideration of the 'over-parameterisation' issue noted within Windrum et al. (2007). Other parameters in the model could also be used for calibration but the model is less sensitive to them. The 'calibration values' 
demonstrate parameter values which range from having limited impact on model results to values which have a greater impact. The range of calibration values within Table A.1 was arrived at through numerous trials exploring the impact of the three variables selected. The range represents a "small" through to "large" impact for each variable.

For calibration purposes, each combination of the three calibrated parameters was run 100 times using a random seed from 1 to 100 to remove stochastic effects within the model (24,500 runs in total). The 'values with best fit' column indicates the range of values for the 15 model specifications which best fit the diffusion curve from Rehmatulla et al. (2015); fit was calculated using the residual sum of squares ('RSS'). These calibration results show that the model is more sensitive to the parameters for the impact of the technology provider agents and the demonstration project, and less sensitive to the value for the expectations spillover effect. The final column shows the combination of calibrated values selected as most appropriate; this combination provided the best fit whilst also representing mid-range values for the $T P_{\text {EXincr }}$ and EX spillover parameters. Figure A.1 compares the model results for the final calibrated values to the diffusion curve in Rehmatulla et al. (2015).

Table A.1: Model calibration parameters

\begin{tabular}{llll}
\hline Parameter & Calibration values & Values with best fit & Calibrated values \\
\hline$T P_{\text {EXincr }}$ & $0.05,0.1, \mathbf{0 . 1 5}, 0.2,0.25,0.3,0.35$ & $0.15-0.25$ & 0.15 \\
EX & $0.025,0.05, \mathbf{0 . 0 7 5}, 0.1,0.125,0.15,0.175$ & $0.025-0.175$ & 0.075 \\
$D_{\text {EXincr }}$ & $\mathbf{0 . 0 0 2 5}, 0.005,0.075,0.01,0.0125$ & 0.0025 & 0.0025 \\
\hline
\end{tabular}

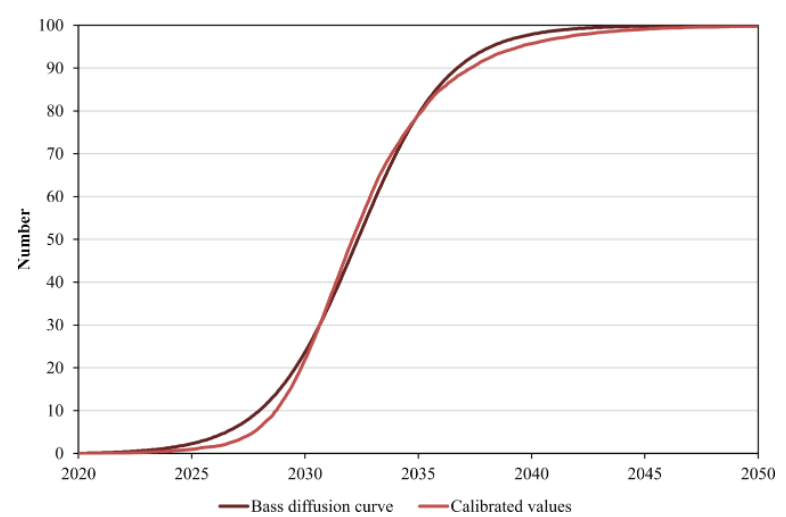

Figure A.1: Model calibration fit (source: Rehmatulla et al. (2015) and author's calculations)

Figure A.1 demonstrates that using mid-range assumptions for calibrated parameters the model demonstrates a good fit with the estimated diffusion curve within Rehmatulla et al. (2015); the calibrated values curve represents an average of 100 runs using the calibrated values. This curve provides validation that the model can reproduce stylised facts from the literature without 'overparameterisation'.

\section{Illustration of multiple model runs}


Figure A. 2 illustrates 25 model runs for the Demonstration Project scenario utilising consistent model parameters (Reference Baseline assumptions plus a single demonstration project). These results are plotted against the average result presented within the paper. This shows the random variation within the model.

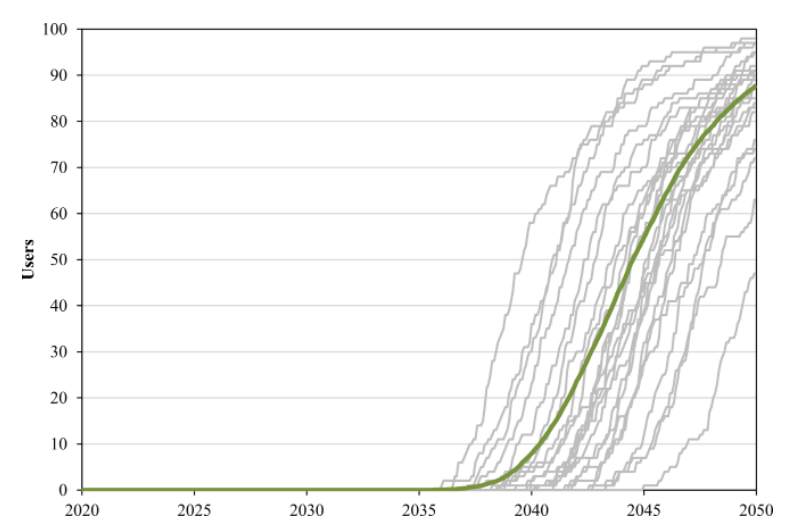

Figure A.2: Illustration of multiple model runs for the Demonstration Project scenario

\section{References}

Ådland, R., Alger, H., Banyte, J., Jia, H. 2017. Does fuel efficiency pay? Empirical evidence from the drybulk timecharter market revisited. Transportation Research Part A: Policy and Practice 95, 1-12.

Agnolucci, P., Smith, T., Rehmatulla, N. 2014. Energy efficiency and time charter rates: Energy efficiency savings recovered by ship owners in the Panamax market. Transportation Research Part A: Policy and Practice 66, 173-184.

Alkemade, F., Suurs, R.A.A., 2012. Patterns of expectations for emerging sustainable technologies. Technological Forecasting and Social Change 79, 448-456.

Bakker S, Maat K, van Wee B. 2014. Stakeholder interests, expectations and strategies regarding the development and implementation of electric vehicles: the case of the Netherlands. Transp. Res. Part A Policy and Practice 66, 52-64.

Baranzini, A., van den Bergh, J.C.J.M., Carattini, S., Howarth, R.B., Padilla, E., Roca, J. 2017. Carbon pricing in climate policy: seven reasons, complementary instruments and political economy considerations. Wiley Interdisciplinary Reviews: Climate Change 8 (4), e462

Bass, F.M. 1969. A New Product Growth for Model Consumer Durables. Management Science 15(5), 215-227.

Bazari, Z., Longva, T. 2011. Estimated $\mathrm{CO}_{2}$ emissions reduction from introduction of mandatory technical and operational energy efficiency measures for ships. IMO MEPC 63/INF.2

Berkhout, P.H.G., Muskens, J.C., Velthuijsen, J.W., 2000. Defining the rebound effect. Energy Policy 28, 425-432.

Budde, B., Alkemade, F., Weber, K.M. 2012. Expectations as a key to understanding actor strategies in the field of fuel cell and hydrogen vehicles. Technological Forecasting and Social Change 79, 1072-1083. http://dx.doi.org/10.1016/j.techfore.2011.12.012.

Buhaug, Ø., Eyring, V., Corbett, J., Endresen, Ø., Faber, J., Hanayama, S., Lee, S., Lee, D., Lindstad, H., Markowska, A., Mjelde, A., Nelissen, D., Nilsen, J., Pålsson, C., Wanquing, W., Winebrake, J. and Yoshida, K. 2009 Second IMO GHG study: Update of the 2000 IMO GHG study, International Maritime Organisation, London.

Cames, M., Graichen, J., Siemons, A., Cook, V. 2015. Emission reduction targets for international aviation and shipping, http://www.europarl.europa.eu/RegData/etudes/STUD/2015/569964/ IPOL_STU(2015)569964_EN.pdf (Accessed June $6^{\text {th }} 2018$ ) 
Cariou, P., Cheaitou, A. 2012. The effectiveness of a European speed limit versus an international bunker-levy to reduce $\mathrm{CO}_{2}$ emissions from container shipping Transportation Research Part D: Transport and Environment 17(2), 116-123.

Eide, M.S., Longva, T., Hoffmann, P., Endresen, Ø., Dalsøren, S.B. 2011. Future cost scenarios for reduction of ship $\mathrm{CO}_{2}$ emissions. Maritime Policy \& Management 38(1), 11-37.

Epstein, J.M., Axtell, R.L. 1996. Growing Artificial Societies: Social Science from the Bottom Up. The MIT Press.

Epstein, J.M., 2007. Generative Social Science: Studies in Agent-Based Computational Modeling. Princeton University Press.

Geels, F.W. 2002. Technological Transitions as Evolutionary Reconfiguration Processes: A multilevel perspective and a case-study. Research Policy 31(8-9), 1257-1274.

Geels, F.W. 2004. From sectoral systems of innovation to socio-technical systems: Insights about dynamics and change from sociology and institutional theory. Research Policy 33(6-7), 897920.

Geels, F.W., Schot, J. 2007. Typology of sociotechnical transition pathways. Research Policy 36(3), 399-417.

Geels, F.W., Kern, F., Fuchs, G., Hinderer, N., Kungl, G., Mylan, J., Neukirch, M., Wassermann, S., 2016. The enactment of socio-technical transition pathways: A reformulated typology and a comparative multi-level analysis of the German and UK low-carbon electricity transitions (1990-2014). Research Policy 45(4), 996-913.

Geroski, P.A. 2000. Models of technology diffusion. Research Policy 29(4-5), 603-625.

Global Maritime Energy Efficiency Partnerships (GloMEEP) 2017. Flettner rotors. http://glomeep.imo.org/technology/-flettner-rotors/ (accessed 13/9/2018)

Grimm, V., Berger, U., De Angelis, D.L., Polhill, J.G., Giske, J. and Railsback, S.F. 2010. The ODD protocol: A review and first update. Ecological Modelling 221(23), 2760-2768.

Grubb, M. 2014. Planetary Economics: Energy, climate change and the three domains of sustainable development, Routledge, Oxon.

Hoogma, R. 2000. Exploiting Technological Niches: Strategies for Experimental Introduction of Electric Vehicles, PhD Thesis, University of Twente, Enschede

Hoogma, R., Kemp, R., Schot, J., Truffer, B. 2002. Experimenting for Sustainable Transport: The approach of strategic niche management, Spon Press, London.

Holtz, G., Alkemade, F., de Haan, F., Köhler, J., Trutnevyte, E., Luthe, T., Halbe, J., Papachristos, G., Chappin, E., Kwakkel, J., Ruutu, S. 2015. Prospects of modelling societal transitions: Position paper of an emerging community. Environmental Innovation and Societal Transitions 17, 41-58.

IMO 2010. Reduction of GHG emissions from ships: Full report of the work undertaken by the Expert Group on Feasibility Study and Impact Assessment of possible Market-Based Measures, MEPC 61/INF.2, Marine Environment Protection Committee, [Online] available from: http://www.imo.org/en/OurWork/environment/pollutionprevention/airpollution/documents/inf -2.pdf [Accessed June 6th 2018]

IPCC 2014. Climate change 2014: Synthesis report. Contribution of working groups I, II and III to the Fifth Assessment Report of the Intergovernmental Panel on Climate Change, [Core Writing Team, R.K. Pachauri and L.A. Meyer (Eds.)], IPCC, Geneva.

Jafarzadeh, S., Utne, I.B. 2014. A framework to bridge the energy efficiency gap in shipping. Energy 69, 603-612,

Jaffe, A.B. Stavins, R.N. 1994. The energy-efficiency gap: What does it mean?. Energy Policy 22(10), 804-810.

Johnson. H., Andersson, K. 2016. Barriers to energy efficiency in shipping. WMU Journal of Maritime Affairs 15, 79-96.

Johnson, H., Johansson, M., Andersson, K. 2014. Barriers to improving energy efficiency in short sea shipping: An action research case study. Journal of Cleaner Production 66, 317-327. 
Kemp, R., Schot, J., Hoogma, R. 1998. Regime shifts to sustainability through processes of niche formation: The approach of strategic niche management. Technology Analysis \& Strategic Management 10(2), 175-198.

Kennedy, D., Bellamy, O., Gault, A., Golborne, N., Hall, T., Haynes, J., Ibitoye, I., Sarda, M., Smith, S., Towers, E., Wilson, J. 2011. Review of UK Shipping Emissions, Committee on Climate Change, London.

Köhler, J., Whitmarsh, L., Nykvist, B., Schilperoord, M., Bergman, N., Haxeltine, A. 2009. A transitions model for sustainable mobility. Ecological Economics 68(12), 2985-2995.

Lloyd's Register 2015. Wind-powered shipping: A review of the commercial, regulatory and technical factors affecting uptake of wind-assisted propulsion, Lloyd's Register Marine, [Online] available from: www.lr.org [Accessed June 6th 2018]

Lopolito, A., Taylor, R., Morone, P. 2014. Emerging innovation niches model. CoMSES Computational Model Library. https://www.comses.net/codebases/4342/releases/1.0.0/ (accessed June $6^{\text {th }}$ 2018)

Lopolito, A., Morone, P., Taylor, R. 2013. Emerging innovation niches: An agent based model. Research Policy 42(6-7), 1225-1238.

Mander, S. 2017. Slow steaming and a new dawn for wind propulsion: A multi-level analysis of two low carbon shipping transitions. Marine Policy 75, 210-216.

Naber, R., Raven, R., Kouw, M., Dassen, T. 2017. Scaling up sustainable energy innovations. Energy Policy 110, 342-354.

Nelissen, D., Traut, M., Köhler, J., Mao, W., Faber, J., Ahdour, S. 2016. Study on the analysis of market potentials and market barriers for wind propulsion technologies for ships, CE Delft, http://www.cedelft.eu/publicatie/study_on_the_analysis_of_market_potentials_and_market barriers for_wind_propulsion technologies_for_ships/1891 [accessed June $6^{\text {th }} 2018$ ]

Nelson, R.R., Winter, S.G. 1982. An Evolutionary Theory of Economic Change. 1st Edition, Harvard University Press, Boston.

Papachristos, G. 2011. A system dynamics model of socio-technical regime transitions. Environmental Innovation and Societal Transitions 1 (2), 202 - 233.

Papachristos, G., Sofianos, A., Adamides, A., 2013. System interactions in socio-technical transitions: Extending the multi-level perspective. Environmental Innovation and Societal Transitions 7, 53 - 69. https://doi.org/10.1016/j.eist.2013.03.002

Papachristos, G. 2014. Towards multi-system sociotechnical transitions: why simulate. Technology Analysis \& Strategic Management 26(9), 1037-1055. https://doi.org/10.1080/09537325. 2014.944148.

Papachristos, G. 2017. Diversity in technology competition: The link between platforms and sociotechnical transitions. Renewable and Sustainable Energy Reviews 73, 291-306.

Papachristos, G., 2018a. A mechanism based transition research methodology: Bridging analytical approaches. Futures 98, 57-71. https://doi.org/10.1016/j.futures.2018.02.006

Papachristos, G., 2018b. System dynamics modelling and simulation for sustainability transition research. In press Environmental Innovation and Societal Transitions https://doi.org/10.1016/j.eist.2018.10.001

Prakash, V., Smith, T., Rehmatulla, N., Mitchell, J., Ådland, R. 2016. Revealed preferences for energy efficiency in the shipping markets, UCL Energy Institute, London. https://d231jw5ce53gcq.cloudfront.net/wpcontent/uploads/2017/04/Shipping_Report_Reveale d_Preferences_Energy_Efficiency_in_Shipping_Markets.pdf (accessed June 6th 2018)

Raucci, C., Prakash, V., Rojon, I., Smith, T., Rehmatulla, N., Mitchell, J. 2017. Navigating Decarbonisation: An approach to evaluate shipping's risks and opportunities associated with climate change mitigation policy. UMAS, London. https://www.u-mas.co.uk (accessed June $6^{\text {th }}$ 2018)

Raven, R., Kern, F., Verhees, B., Smith, A. 2016. Niche construction and empowerment through socio-political work. A meta-analysis of six low-carbon technology cases. Environmental Innovation and Societal Transitions 18, 164-180. 
Rehmatulla, N., Hosseinloo, S.H., Smith, T., Calleya, J. 2015. The diffusion of energy efficiency technologies in shipping. Shipping in Changing Climates Conference. http://www.lowcarbonshipping.co.uk [accessed June $6^{\text {th }} 2018$ ]

Rehmatulla, N., Calleya, J., Smith, T. 2017a. The implementation of technical energy efficiency and $\mathrm{CO}_{2}$ emission reduction measures in shipping. Ocean Engineering 139, 184-197.

Rehmatulla, N., Parker, S., Smith, T., Stulgis, V. 2017b. Wind technologies: Opportunities and barriers to a low carbon shipping industry. Marine Policy 75, 217- 226.

Rehmatulla, N., Smith, T. 2015. Barriers to energy efficiency in shipping: A triangulated approach to investigate the principal agent problem. Energy Policy 84, 44-57.

Rip, A., Kemp, R. 1998. Technological Change. In: Rayner, S. and Malone, E.L. (eds.), Human Choice and Climate Change, vol 2. Battelle Press, Columbus, pp.327-399

Rogers, E.M. 2003. Diffusion of Innovations. 5th edition, Free Press, New York.

Rojon, I., Dieperink, C. 2014. 'Blowin' in the wind? Drivers and barriers for the uptake of wind propulsion in international shipping. Energy Policy 67, pp.394-402.

Rosenberg, N. 1976. Perspectives on Technology. Cambridge University Press, Cambridge.

Rubin, E.S., Azevedo, I.M.L., Jaramillo, P., Yeh, S. 2015. A review of learning rates for electricity supply technologies. Energy Policy 86, 198-218.

Safarzyńska, K., van den Bergh, J.C.J.M., 2010. Demand-supply coevolution with multiple increasing returns: policy analysis for unlocking and system transitions. Technological Forecasting and Social Change 77, 297-317.

Safarzynska K., Frenken K., van den Bergh J.C.J.M., 2012. Evolutionary theorizing and modeling of sustainability transitions. Research Policy 41, 1011-1024.

Schäfer, A.W., Evans, A.D., Reynolds, T.G., Dray, Lynnette 2016. Costs of mitigating $\mathrm{CO}_{2}$ emissions from passenger aircraft. Nature Climate Change 6, 412-418.

Schot, J., Geels, F.W., 2007. Niches in evolutionary theories of technical change. Journal of Evolutionary Economics, 17, 605-622.

Schot, J., Geels, F.W. 2008. Strategic niche management and sustainable innovation journeys: Theory, findings, research agenda, and policy. Technology Analysis \& Strategic Management 20(5), 2008, 537-554.

Schot, J., Hoogma, R., Elzen, B. 1994. Strategies for shifting technological systems: The case of the automobile system. Futures 26(10), 1060-1076.

Senger, F., Köhler, J. 2015. Transitions to low carbon ship propulsion technologies including wind, simulated with an agent-based model using evolutionary approaches. Shipping in Changing Climates Conference. http://www.lowcarbonshipping.co.uk [accessed June 6th 2018]

Smith, A., Raven, R. 2012. What is protective space? Reconsidering niches in transitions to sustainability. Research Policy 41(6), 1025-1036.

Smith, T., Jalkanen, J., Anderson, B., Corbett, J., Faber, J., Hanayam, S., O’Keefe, E., Parker, S., Johansson, L., Aldous, L., Raucci, C., Traut, M., Ettinger, S., Nelissen, D., Lee, D., Ng, S., Agarwal, A., Winebrake, J., Hoen, M., Chesworth, S., Pandey, A. 2014. Third IMO GHG Study, International Maritime Organisation, London.

Smith, T., Newton, P., Winn, G., Grech La Rosa, A. 2013a. Analysis techniques for evaluating the fuel savings associated with wind assistance. Low Carbon Shipping Conference, London, www.lowcarbonshipping.co.uk [accessed June $6^{\text {th }} 2018$ ]

Smith, T., O'Keeffe, E., Aldous, L., Agnolucci, P. 2013b. Assessment of Shipping's Efficiency Using Satellite AIS Data, UCL Energy Institute, London.

Smith, T., Raucci, C., Haji Hosseinloo, S., Rojon, I., Calleya, J., Suarez de la Fuente, S., Wu, P., Palmer, K. 2016. $\mathrm{CO}_{2}$ emissions from international shipping: Possible reduction targets and their associated pathways, UMAS, London.

Sorrell, S., O’Malley, E., Schleich, J., Scott, S. 2004. The Economics of Energy Efficiency: Barriers to Cost-Effective Investment. Edward Elgar, Cheltenham and Northampton.

Strachan, N. 2011. Business-as-Unusual: Existing policies in energy model baselines. Energy Economics 33(2), 153-160. 
Tesfatsion, L. 2006. Chapter 16, Agent-Based Computational Economics: A Constructive Approach to Economic Theory. In: Schmedders, K. and Judd, L. (eds.), Handbook of Computational Economics, Volume 3. Elsevier, Amsterdam, pp.831-880.

Thiele, J.C., Kurth, W., Grimm, V. 2014. Facilitating Parameter Estimation and Sensitivity Analysis of Agent-Based Models: A Cookbook Using NetLogo and R. Journal of Artificial Societies and Social Simulation 17(3), http://jasss.soc.surrey.ac.uk/11-/3/7.html

Traut, M., Gilbert, P., Walsh, C., Bows, A., Filippone, A., Stansby, P., Wood, R. 2014. Propulsive power contribution of a kite and Flettner rotor on selected shipping routes. Applied Energy 113, 362-372.

UNFCCC 2015. Adoption of the Paris Agreement, https://unfccc.int/resource/docs/2015/cop21/eng/ 109r01.pdf [accessed June $6^{\text {th }} 2018$ ]

Unruh, G.C. 2000. Understanding carbon lock-in. Energy Policy 28(12), 817-830.

van Lente, H., Spitters, C., Peine, A., 2013. Comparing technological hype cycles: Towards a theory. Technological Forecasting and Social Change 80, 1615-1628.

Veenstra, A.W., Van Dalen, J. 2011. Ship speed and fuel consumption quotation in ocean shipping time charter contracts. Journal of Transport Economics and Policy 45(1), 41-61.

Vivid Economics 2010. Assessment of the economic impact of market-based measures. http://www.imo.org/en/OurWork/environment/pollutionprevention/airpollution/-documents/ inf-2.pdf [accessed June $6^{\text {th }} 2018$ ]

Wang, H., Faber, J., Nelissen, D., Russell, B., St Amand, D. 2010. Marginal abatement costs and cost effectiveness of energy-efficiency measures. IMO MEPC 61/INF.18 https://www.cedelft.eu/publicatie/marginal_abatement_costs_and_cost-effectiveness_of energy-efficiency_measures/1090 (accessed June $6^{\text {th }} 2018$ )

Wang, H., Lutsey, N. 2013. Long-term potential for increased shipping efficiency through the adoption of industry-leading practices. The International Council on Clean Transportation, Washington.

Ward, W.H. 1967. The sailing ship effect. Physics Bulletin 18(6), 169.

Werker, C., Brenner, T. 2004. Empirical Calibration of Simulation Models. Papers on Economics and Evolution, no0410. http://hdl.handle.net/10419/88244 [Accessed June 6th 2018]

Windrum, P., Fagiolo, G., Moneta, A. 2007. Empirical Validation of Agent-Based Models: Alternatives and Prospects. Journal of Artificial Societies and Social Simulation 10(2) http://jasss.soc.surrey.ac.uk/10/2/8.html 